\title{
DOS SILLAS EN EL PABELLÓN ESPAÑOL DE LA XI TRIENAL DE MILÁN: EL DISEÑO QUE QUERÍA EMERGER EN 1957
}

\author{
TWO CHAIRS IN THE SPANISH PAVILION OF THE MILAN XI TRIENNIAL: \\ THE DESIGN THAT WANTED TO EMERGE IN 1957
}

Oriol Pibernat Domènech*

EINA, Centro Universitario de Diseño y Arte de Barcelona

\section{Resumen}

España estuvo presente oficialmente en la Trienal de Milán en tres ediciones consecutivas: en 1951, 1954 y 1957. En la edición de 1957 se presentaron dos variantes del sillón Toro de Miguel Fisac y de la tumbona Barceloneta de Federico Correa y Alfonso Milá, entre otras piezas de artes aplicadas y artesanía. El diseño de estos muebles y, sobre todo, las razones de su presencia en la Trienal son el motivo de esta investigación.

Tras dos ediciones de la Trienal en las que España había cosechado éxitos mostrando obras de arte contemporáneo, piezas de arte decorativo y ejemplos de la cultura material popular, el pabellón de 1957 incorporó unos objetos que se ajustaban mejor a los nuevos parámetros del diseño. Su presencia fue indicativa del progreso, pero también de las contradicciones, del movimiento en pro del diseño en sus primeros intentos de crear plataformas de asociación y promoción en Barcelona y Madrid.

Palabras clave: Diseño y franquismo, Miguel Fisac, Federico Correa y Alfonso Milá, Javier Carbajal, artesanía y diseño, diseño en España.

\section{Abstract}

Spain was officially present at the Milan Triennial in three consecutive editions: in 1951, 1954 and 1957. In the 1957 edition there were presented two variants of the Toro armchair from Miguel Fisac and the Barceloneta deckchair by Federico Correa and Alfonso Milá, in between others art and craft pieces. The design of this furniture and, especially, the reasons for its presence there configures the subjects of this investigation.

After two editions of the Triennial in which Spain had been successful showing contemporary works of art, decorative art pieces and examples of popular material culture, the 1957 pavilion incorporated, for the first time, furniture created from the new parameters of design. Their presence was indicative of the progress of the movement for design that led to the first attempts to create platforms and associations in Barcelona and Madrid.

Keywords: Design and Francoism, Miguel Fisac, Federico Correa and Alfonso Milá, Javier Carbajal, arts and craft and industry, Spanish design. 
En la década de los cincuenta los arquitectos más comprometidos con la renovación de la arquitectura española pusieron su empeño en el diseño de muebles. Con ello seguían el ejemplo de los grandes maestros europeos y americanos que aspiraban a un diseño integral de sus obras. En el caso español tal actitud respondía, así mismo, a una necesidad acuciante: disponer de un equipamiento acorde a los deseos de modernidad que inspiraban sus obras ya que, en aquellos años, no había posibilidad alguna de encontrar en el mercado español mueble moderno. Miguel Fisac, uno de los más aventajados en aquel compromiso, sintetizaba con unas pocas palabras la situación: "A hacer muebles me llevó el hecho de que si no era yo quien diseñaba el mobiliario para el interior de mis obras, todas las habitaciones de mis proyectos estarían ocupadas por horrendos muebles de época". ${ }^{1}$ Tal planteamiento se puede considerar el punto de partida que induciría a algunos arquitectos a diseñar muebles y, más tarde, a ir al encuentro de la idea de diseño industrial.

\section{Renovación arquitectónica y diseño de muebles: orígenes de los mo- delos Toro y Barceloneta}

Fisac dedicó tiempo y esmero a la tarea de proyectar el equipo mobiliario de sus encargos. De hecho, probablemente se trate de un caso ejemplar dentro de la arquitectura española tanto por el alcance y los logros como por lo temprano de dicha actitud en aquel contexto. Este tipo de empresa arranca con sus encargos de los años cuarenta y principalmente para los edificios del CSIC, Consejo Superior de Investigaciones Científicas: su sede central (1943), el Instituto de Edafología (1944), la Biblioteca Goerres (1947), el Instituto de Óptica (1948) y la Librería del CSIC (1950). Para estas obras estableció concienzudos programas de equipamiento interior y diseñó desde picaportes a todo tipo de mobiliario específico. Precisamente es en uno de estos proyectos, la Biblioteca hispano-alemana Goerres, donde encontramos los primeros dibujos de la butaca Toro que coprotagoniza este artículo. Dichos dibujos datan de c. 1948 y forman parte de un programa de mobiliario denominado Serie estructural para la Biblioteca. Fisac describe el programa en estos términos:

Para la sala de lectura y depósito de libros de la Fundación Goerres del C.S.I.C. hacia 1948. Al tener que hacer una serie de muebles: sillas, butacas, bancos, taburetes, mesas, mesas auxiliares, mesas de centro, armarios, estanterías, etc., todos ellos de madera (ordinariamente de roble) pensé separar lo propiamente estructural de cada mueble, de las piezas de uso directo: asientos, respaldos, tableros de mesa, estanterías, etc.

Como teoría estructural pensé crear una organización rectangular y distinguir las diferentes piezas de que se componga, manteniendo secciones constantes y normalizadas de las piezas; las que han de trabajar en la estructura a esfuerzos de compresión, con secciones cuadradas, generalmente de 30x30 mm. Esfuerzos de flexión de 30 x 60 mm y esfuerzos de tracción- unidos siempre a las otras piezas por caja y espiga- de 30 ×30 $\mathrm{mm}$ que se va estrechando desde la espiga hasta quedar en el centro del vano de 15 x $15 \mathrm{~mm}$. 
A la estructura necesaria para la estabilidad del mueble, se le adosa- con tornillos o ensambles encolados- el asiento, el respaldo, el tablero etc. ${ }^{2}$

La descripción detalla a la perfección la inclinación constructiva, el instinto experimental y la vocación normalizadora propias de Fisac; además de un no muy usual conocimiento de la carpintería. Así se constata como el diseño y dimensionamiento de la madera busca una perfecta coherencia morfológica con el tipo de esfuerzos de la estructura. Es decir, el diseño parece sugerir la forma del esfuerzo, que en las patas es el de la compresión, en las vigas el de la flexión y en los travesaños el de la tracción; siendo en éstos donde se hace literalmente evidente.

Dentro de esta serie, que incluía diversos modelos de mesas y asientos, encontramos un primer dibujo de una butaca baja, de unos $35 \mathrm{cms}$ de altura, con su asiento y respaldo tapizado de goma espuma y recubrimiento. Del respaldo se prolongan sus característicos reposabrazos con forma de astado que motivará el nombre de la butaca. ${ }^{3}$ Existen otros planos con más detalle en documentos posteriores de 1954 para las instalaciones del Teologado de los Dominicos en Alcobendas (fig. 1).

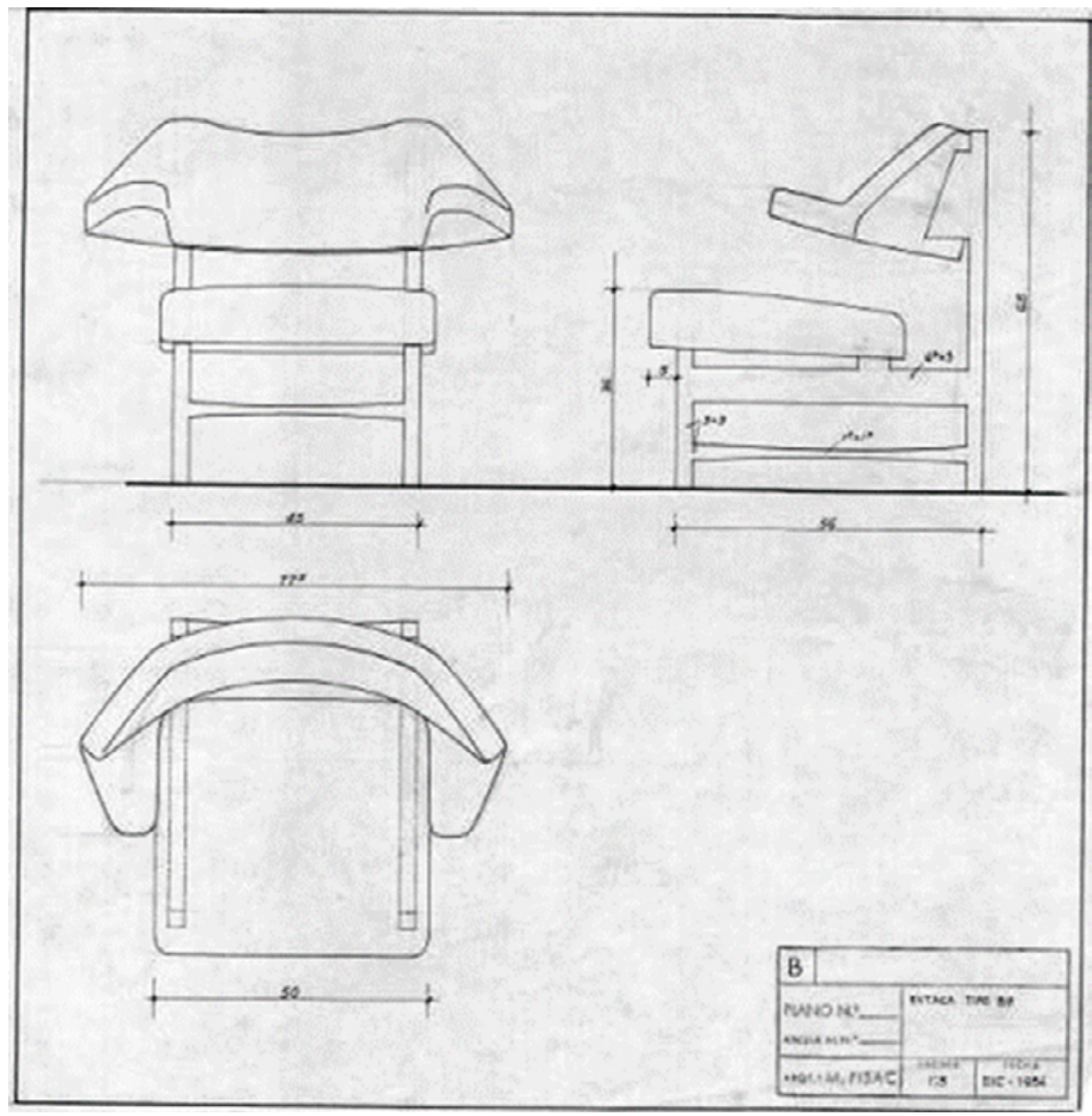

Fig.1. Planos de la silla Toro de 1954 para las instalaciones del Teologado de los Dominicos en Alcobendas. Imagen cedida por la Fundación Fisac (Identificado como B8). 
La imagen de la butaca es el resultado del contraste de un severo esqueleto que acoge un asiento y respaldo con brazos mullidos que garantizan la funcionalidad en términos de confort. Fisac distingue visualmente tales elementos de manera que parecen partes cuasi exentas. Una radicalidad enfatizada visualmente al situar el asiento elevado del travesaño y al separar el anclaje del respaldo de los montantes mediante unas cuñas. Así se acentúa un juego de oposiciones entre linealidad y volumen o entre ingravidez y masa. Ergonómicamente, es importante destacar la inclinación del asiento, ligeramente elevado en la parte delantera, y la inclinación del respaldo, gracias a las mencionadas cuñas. Ambas inclinaciones y la forma curva del respaldo que se prolonga con los dos brazos acogen el cuerpo en posición de relajo.

En los años siguientes a la Biblioteca Goerres, Fisac incorporó la butaca a diferentes proyectos e incluso realizó de ella diversas versiones. Las fotografías de los interiores nos permiten reconocerla en la Casa Larragueta (1954), en la Casa Fisac en Cerro del Aire, (1956), o en las dependencias monacales del Teologado de los Dominicos en Alcobendas (1955-1958), entre otras. La vemos en madera de roble o de haya; tapizada en cuero, piel de vaca, escay o diversos tipos de telas; de un cuerpo, de dos y de tres. Pero aquello más destacable es que, a partir del modelo original de madera, se deriva otro modelo con estructura de metal. Dicha estructura la forman tres piezas de tubo de hierro doblado (de sección redonda o cuadrada, según los casos) soldadas entre sí que se estabilizan sujetas al asiento y al respaldo. El esqueleto metálico simplifica la estructura ya que permite suprimir el travesaño frontal y los laterales inferiores. Además, es la propia estructura de tubo la que se pliega con un gesto que fortalece el trabajo en flexión y compresión. En este modelo se acentúa aún más el contraste entre ligereza y masa, antes mencionado (fig. 2).
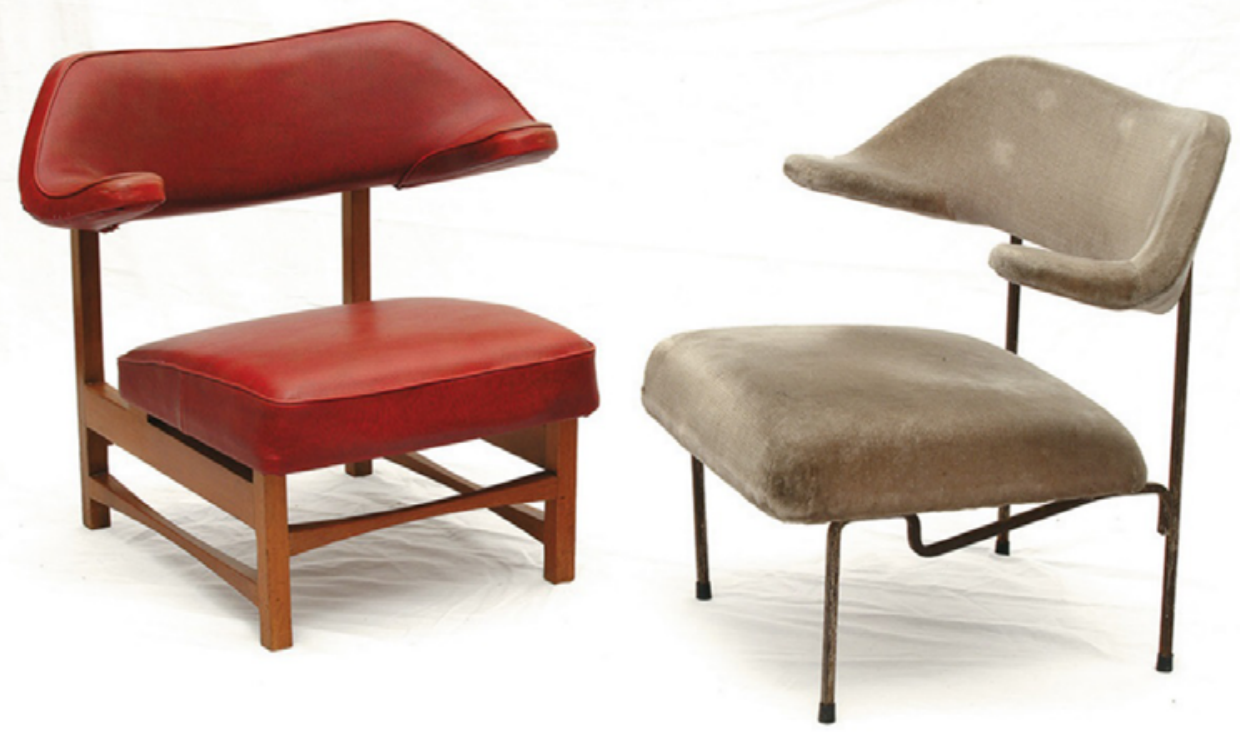

Fig.2. Las dos versiones de la butaca Toro con estructura de madera y con estructura de tubo metálico. Imagen COAM. 
Mientras que para la casa Larragueta (1953) las butacas Toro son de estructura de roble, las de la casa de Fisac (1956) son de estructura de metal. Algún autor vinculan este abandono de la madera con "el aumento de la audacia formal en sus estructuras" que se da, tanto en su arquitectura como en su mobiliario, a medida que avanza la década de los cincuenta. ${ }^{4} \mathrm{Si}$ se comparan la Librería del CSIC de 1950 con el interior de la Librería Europa de 1952, se observará la misma tendencia. A partir de tal razonamiento podría fecharse la versión de estructura de metal entre 1952 y 1956.

La butaca Toro es un buen ejemplo de las investigaciones de Fisac en el campo del mobiliario para sus obras. Como decíamos, ese fue un interés compartido con otros arquitectos españoles de su generación. Es el caso de Alejandro de la Sota, Francisco Javier Sáenz de Oiza, o Javier Carvajal que se ocuparon, en un momento u otro, del mobiliario. El afán por un dominio ambiental del espacio interior en sus proyectos define igualmente la arquitectura de José Antonio Coderch. Éste no se prodigó tanto en el diseño de muebles para sus interiores como Fisac. Sin embargo, logró grandes efectos con unos pocos diseños básicos como la lámpara Disa o las chimeneas Capilla y Polo. Por otra parte, a menudo resolvió cuestiones de mobiliario con soluciones de albañilería, en especial en su fecunda labor para segundas residencias.

Precisamente, el segundo mueble que protagoniza este estudio se relaciona con el estudio Coderch-Valls. La tumbona Barceloneta fue diseñada en 1954 por Federico Correa y Alfonso Milá a raíz de un encargo de colaboración propuesto por el estudio de Coderch. En la fase final de la obra del edificio de viviendas en el barrio barcelonés de la Barceloneta se pidió a los arquitectos equipar un piso-muestra. Coderch asumió la tarea con el concurso de los jóvenes arquitectos Correa y Milá que en aquel momento colaboraban con su estudio. El piso de muestra, según revelan las fotografías, fue amueblado de acuerdo con el programa funcional y estético del edificio. Se trataba de una promoción del Montepío Marítimo Nacional del Instituto Social de la Marina y respondía al requisito de vivienda social para sus afiliados. Que se tratara de una promoción social con medios limitados no impidió que se observe la misma pulsión de modernidad en el diseño interior y en el mobiliario del piso de muestra que en el conjunto de la obra.

El edificio de viviendas de la Marina ocupa un lugar prominente en la nueva arquitectura española de los años 50 y en la obra de su autor. Se caracteriza por una planta con distribución oblicua que, desde los muros portantes, se traslada tanto a la distribución interior como a la fachada. Como resultado de ese peculiar diseño de geometría no octogonal, los pisos se presentan con unas habitaciones replegadas sobre sí mismas, con espacios marcados por el control filtrado de la luz natural a través de lamas de madera. Las paredes en diagonal acentúan dicho repliegue que, no obstante, promueve el aprovechamiento y la percepción dimensionada de las habitaciones. La luz filtrada otorga al espacio una dignidad ambiental desacostumbrada en la vivienda de promoción social. El piso-muestra presenta una atmósfera interior de aspecto austero, amueblada con pocos elementos, los necesarios, más algunos detalles decorativos (fig. 3). Se trata, por lo tanto, de una vivienda sin voluntad de "aparentar" y sin el repertorio de "conjuntos" de mobiliario convencionales. ${ }^{5}$ 


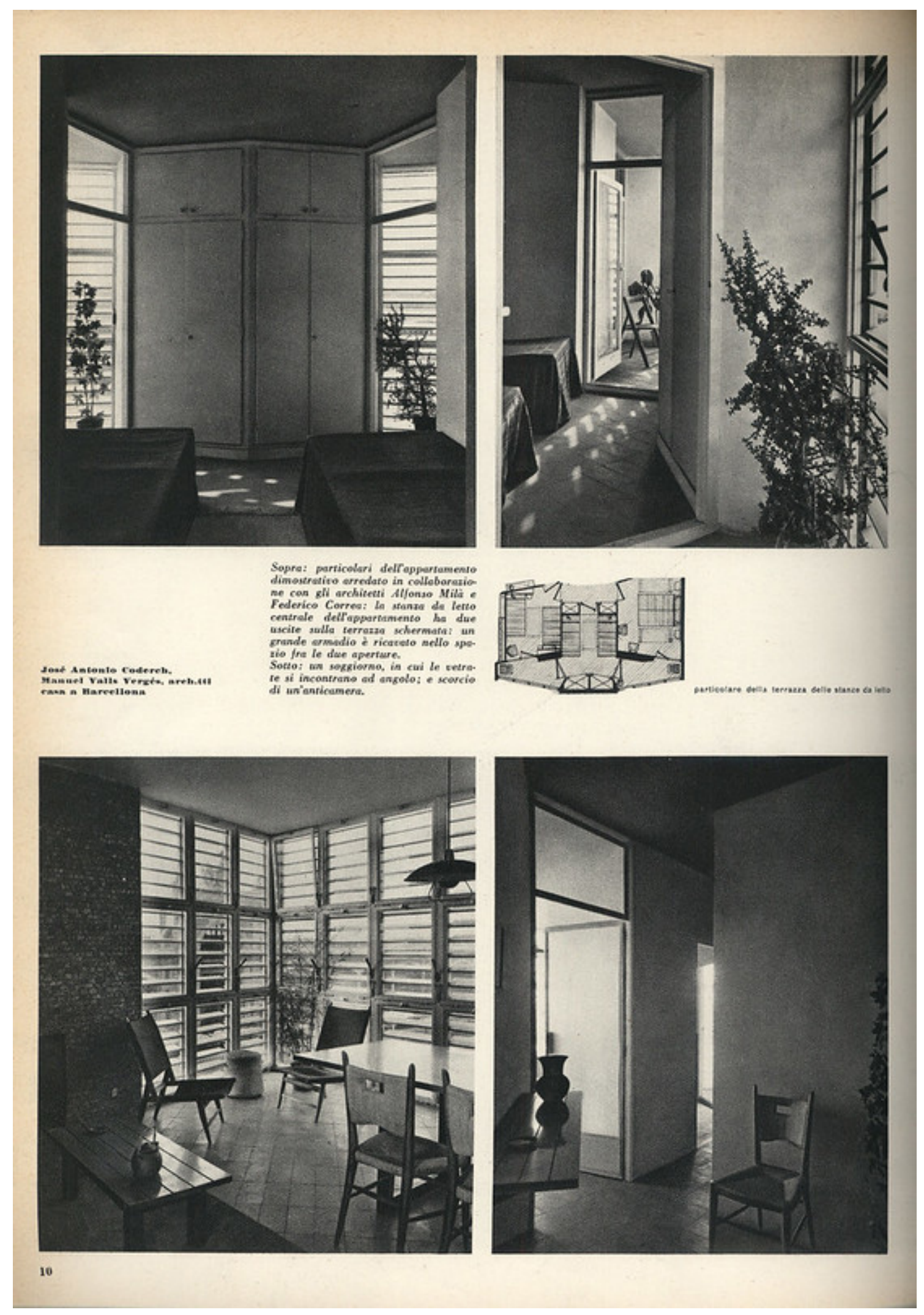

Fig.3. Página de la revista Domus con fotografías del piso-muestra del edificio de la Marina. "Una casa a Barcellona”, Domus nº 325 (diciembre 1956), pág. 10. 
Entre los muebles, y junto a mesas sencillas, destacan la silla Llambí y la tumbona Barceloneta. La silla Llambí es un diseño de Coderch de 1946. La novedad se encuentra en el modelo de asiento diseñado por Correa y Milá. Éste se inspira en las sillas menorquinas y en las tumbonas tradicionales de terraza o playa, ambas de madera y lona. A medio camino entre un tipo y otro, funciona como asiento bajo con funciones de butaca, a $34 \mathrm{~cm}$ del suelo. La estructura es de madera de haya y el asiento y el respaldo lo forman dos fundas de tela de lona con la particular característica de que en el reverso tienen un sistema de cordado, tipo corsé con ojetes, que permite atirantar la lona cuando esta se destensa. La forma trapezoidal de la estructura que asienta al suelo le otorga una completa estabilidad. Pero lo más singular tal vez sea el sistema de engarce que une la pata trasera, la biga del asiento y el montante del respaldo en forma de triángulo. Este ensamblaje triangular consolida el esqueleto a pesar de la inusual altura del respaldo inclinado y, por lo tanto, la fuerza de palanca que se ejerce. Es esta altura la que permite reposar la cabeza y refuerza la apariencia de gandula como invitación a abandonarse al reposo y al tiempo libre (fig. 4).

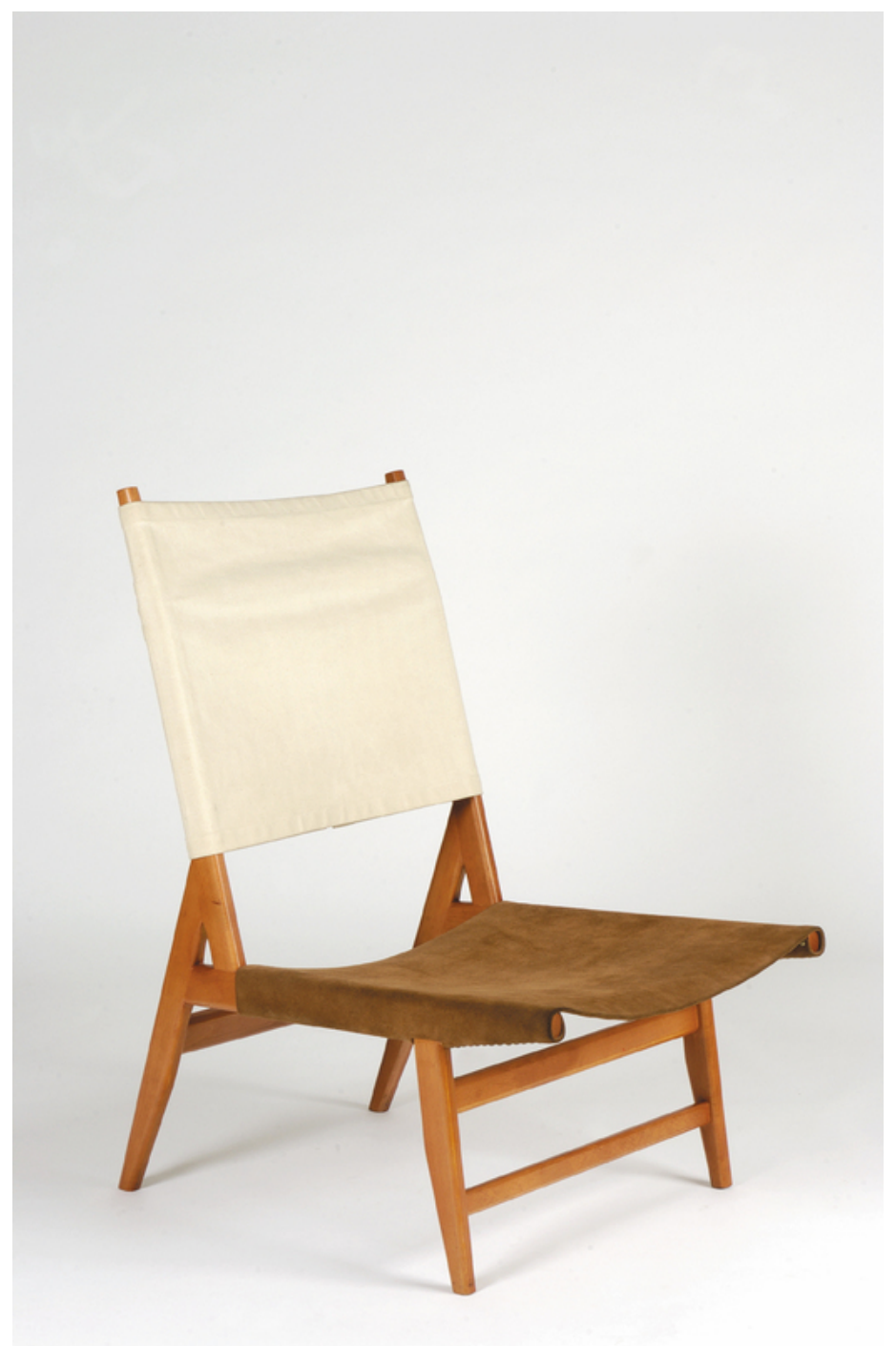

Fig.4. Silla Barceloneta de Federico Correa y Alfonso Milá. Museu del Disseny de Barcelona, MADB 135395. 
Correa y Milá pensaron en un asiento ligero, fácil de mover y que no ocupara demasiado espacio, que igual sirviera para la terraza cubierta y contemplar el afuera como para recogerse alrededor del hogar. Se trataba de lograr un asiento versátil como lo exigía un piso-muestra acorde con una vivienda austera con pocos muebles para distintas funciones. En verdad, existe una relación directa entre el modelo y el ambiente marino de la Barceloneta. El nombre procede precisamente de aquel barrio del litoral de Barcelona. Aunque también se interpreta como un homenaje socarrón a la silla Barcelona de Mies van der Rohe. La ironía del diminutivo se debería, entonces, de la distancia que media ente el uso, los materiales y los precios de la butaca noble y de representación del pabellón alemán y un humilde asiento de loneta inscrito en un programa social. Si una se inspiraba en la silla de los magistrados romanos, la que nos concierne aquí lo hacía en los humildes tipos populares mediterráneos. Precisamente, a sus autores, seguidores del magisterio de Coderch, les ocupaba sus mismas búsquedas: la adaptación de los principios y lenguajes del Movimiento Moderno a las condiciones geográficas, ambientales y productivas locales.

Luego de este uso de equipamiento en la vivienda modelo de pescadores de la Barceloneta en 1954, el asiento fue incorporado a otras obras de CorreaMilá y de Coderch. Alcanzó bastante notoriedad asociada al amueblamiento de segundas residencias en Cadaqués a partir de la casa Villavecchia (1955) o la casa Julià (1956) de los mismos arquitectos (fig. 6). La difusión propició que se introdujeran algunas variantes en el diseño original. Así, se sustituyó la lona del asiento por cuero de piel girada, para ganar rigidez. También apareció una versión con brazos cuyo diseño se resolvía con una prolongación en altura de las patas delanteras a las que se adherían unos pernos perpendiculares y otros a los montantes traseros. Entre el perno de la pata y del montante se disponía una tira de cuero que era propiamente el brazo. Son las sillas que vemos en las fotografías de la Casa Senillosa (1956) de Coderch, también en Cadaqués. ${ }^{6}$ No obstante su carácter estival, ello no impidió que fuera elegida para amueblar pisos urbanos de interiorismo moderno. ${ }^{7}$

\section{Dos pares de sillas para la XI Trienal de Milán}

Que el diseño de estos dos asientos es apreciable está fuera de duda. No obstante, su emparejamiento y realce en este estudio se debe a que ambos fueron seleccionados y exhibidos en el pabellón español de la XI Trienal de 1957. En aquella ocasión se presentaron dos modelos de la butaca Toro y dos de la tumbona Barceloneta. El primer par consistía en una Toro con bastidores de madera y tapizado en tela clara, tipo otomán, estampada a rayas, y la otra con bastidores de hierro curvado y tapizado en tela oscura. En el segundo, se presentaron dos tumbonas Barceloneta en su variante de asiento de cuero; una sin brazos de madera clara y otra con brazos con bastidores de madera oscura.

Cabe interrogarse, entonces, sobre el motivo de tal selección y sobre el papel que jugaban en la muestra española. La pregunta es pertinente dado que la selección de piezas para una exposición responde a una intención, sea más o menos explícita. Además, se trataba de exhibirlo en un pabellón nacional 
en el extranjero, un medio donde los objetos adquieren un fuerte valor de representación; de hecho, bastante análogo a la misma idea de embajada.

La Dirección General de Relaciones Culturales del Ministerio de Asuntos Exteriores (DGRC) puso en manos de los arquitectos Javier Carvajal y José García de Paredes la participación española. Era la tercera vez que España acudía oficialmente a aquella cita. Coderch estuvo a cargo del pabellón en la IX edición de 1951 y el grupo MoGaMo hizo lo propio para la X de 1954. La elección de Carvajal y García de Paredes para aquella tercera ocasión podría explicarse por el conocimiento que ambos tenían del contexto italiano tras su paso por la Academia española en Roma como pensionados, así como por su brillante desempeño proyectando el Panteón de los Españoles en Roma, erigido justo un año antes.

A lo largo de su trayectoria, la Trienal de Milán fue el certamen europeo más importante de arquitectura, artes decorativas y diseño. En aquellas convocatorias se postulaba la integración de las artes y la educación del gusto, y se media el pulso de los intereses y debates internacionales sobre la modernidad. Así fue en la década de los 50. Un somero análisis de las tres ediciones permite subrayar como fue tomando cuerpo la idea y la práctica del diseño industrial. El ciclo se inicia en 1951 con un certamen que ponía sobre la mesa "la integración de las artes" y que, bajo la batuta de la arquitectura, convocaba a las producciones de artistas, artesanos y diseñadores que desarrollaran un concepto moderno del hábitat doméstico, la arquitectura y todo aquello que implicaba el entorno cotidiano. En aquella edición ya se hacía evidente que el incipiente desarrollo social y económico de postguerra traía a primer plano la estética de los bienes de consumo. En consecuencia, la relación entre el arte y la industria sería el eje que acaparara el interés temático de la Trienal de 1954. El protagonismo del diseño industrial sería ya evidente. Los intereses de la Trienal de 1957 fueron más difusos y se inauguró bajo una sensación de crisis de orientación y objetivos. No obstante, la muestra de diseño industrial fue la más completa y articulada de la que dio cuenta la Trienal. Lo que, en cierta manera, vendría ser il canto del cigno de aquella primacía del diseño. ${ }^{8}$ La edición del 57 se celebró con un debate abierto sobre el futuro del certamen y, efectivamente, cerraría el ciclo del diseño industrial pues la Trienal tomaría otros derroteros.

En este contexto se enmarcaba el pabellón español merecedor de una descripción más detallada. Como en anteriores ediciones, la primera planta de la sede de la Trienal se dedicaba a las secciones internacionales. Para la ocasión España había alquilado un espacio estratégicamente situado en el centro. Era un espacio de planta cuadrada y notablemente mayor que el de los dos pabellones de ediciones anteriores. En este espacio Carvajal y García de Paredes crearon una potente imagen escenográfica. Los muros de la sala, revestidos de ladrillo visto, se encalaron. El suelo se pavimentó con una gran superficie de azulejos tradicionales ideada por José María de Labra que combinaba una trama de negro, blanco y azul celeste. Desde el centro se estableció un gran círculo perimetral, de $12 \mathrm{~m}$ de diámetro que se delimitaba con una balla metálica de tipo industrial similar a las que cierran el perímetro de solares y terrenos. Los focos de luz rebotaban en la pared y traspasaban la malla creando un efecto de tamizadas transparencias. 
En la misma malla metálica se colgaban unas ménsulas que acogían cerámicas de Antoni Cumella y otros objetos decorativos de menor tamaño. Las piezas textiles, como los tapices de Jesús de la Sota o los tejidos de Clara Szabó y de Manuel Suarez Molezún, se disponían directamente colgadas a la misma red. En la entrada, a derecha e izquierda, se encontraban vasos de terracota de Fernández Alba y cerámicas policromadas de José Luís Sánchez y de Arcadio Blanco. En el espacio central, en el interior del cercado, se disponían algunos asientos de esparto y unas plataformas circulares -una de $3 \mathrm{~m}$ de diámetro y tres de $2 \mathrm{~m}$ - que parecían flotar sobre el brillante suelo de azulejos. Eran las sencillas peanas para otras piezas de exposición. En las pequeñas se encontraban las maletas y bolsas de Loewe y, en la grande, vidrios verdes de artesanía popular de Mallorca, arte aplicado y los dos pares de asientos de los que venimos hablando (fig. 5).

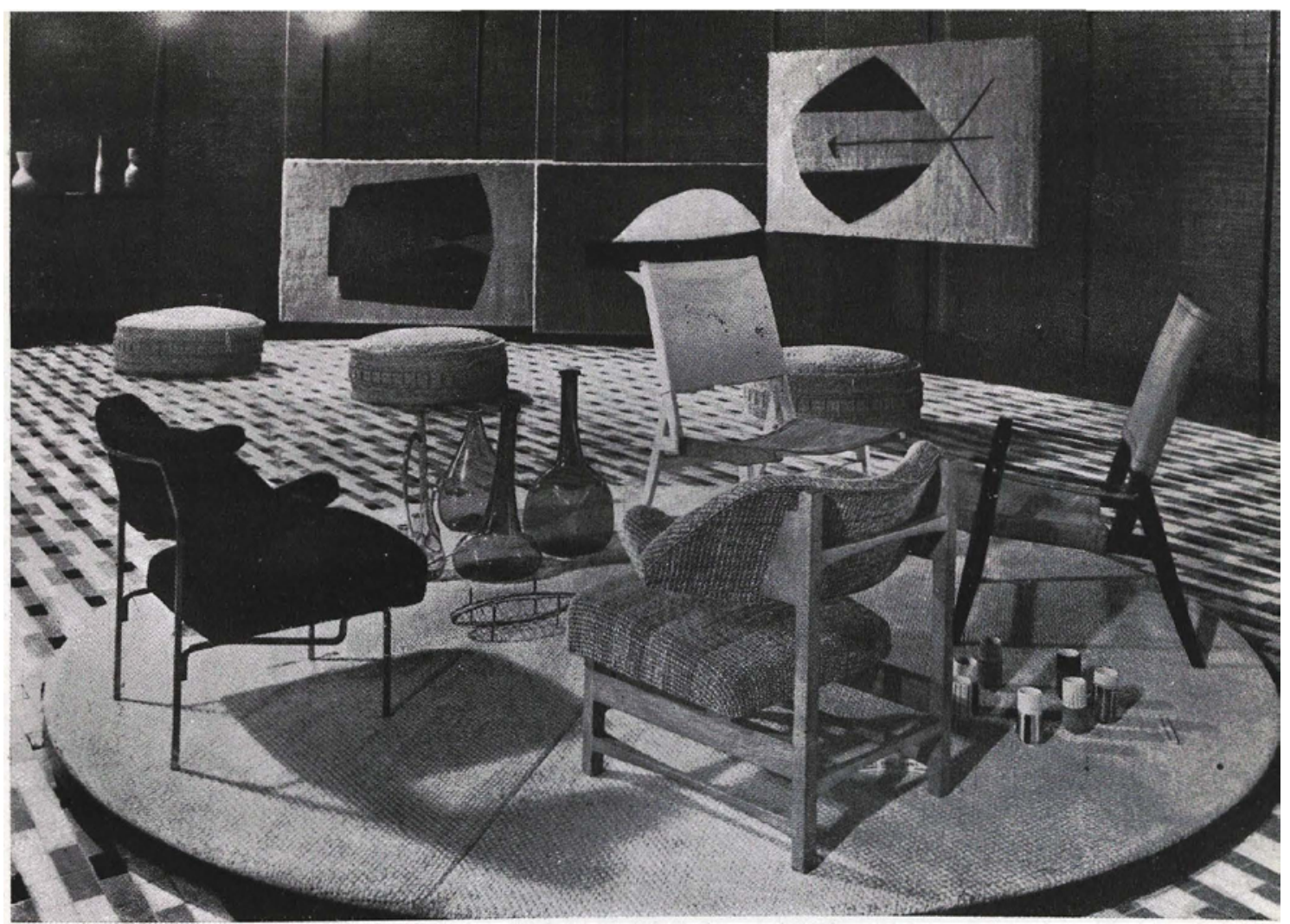

Fig.5. Detalle de la plataforma de muebles del pabellón español de la XI Trienal (1957). Imagen publicada en RNA n ${ }^{\circ}$ 191, noviembre 1957, pág. 35.

Las paredes pintadas a la cal tenían un impacto refulgente. La instalación y el control de la luz, con zonas iluminadas y de penumbra (sol y sombra), otorgaban al espacio un elocuente efecto dramático que evocaba a un coso taurino. Los materiales empleados (cal, azulejo, hierro y madera) remitían a la tradición, pero, por otra parte, ello contrastaba con la reja de propiedades industriales. En todo caso, la abstracción escenográfica evitaba toda figuración folclorista en favor de una alusión más alegórica y sofisticada.

La recepción crítica al pabellón fue muy favorable. En junio apareció un reportaje anunciando lo que sería la representación de España en la Trienal 
en el semanario La Hora. Arte, Letras y Política que dedicaba la portada al suceso. ${ }^{9}$ Venía firmado por el crítico de arte Juan Ramírez de Lucas que también publicaría otro artículo análogo en diciembre en el periódico $A B C$ destacando la obtención de la Medalla de oro para la instalación. ${ }^{10}$ En éste, Ramírez de Lucas reconocía el pabellón de Finlandia y el de España como los mejores. Aunque admitía que era parco en objetos expuestos, destacaba que era el único capaz de transmitir el ambiente característico de su país en un lenguaje arquitectónico y escenográfico moderno (fig. 6).

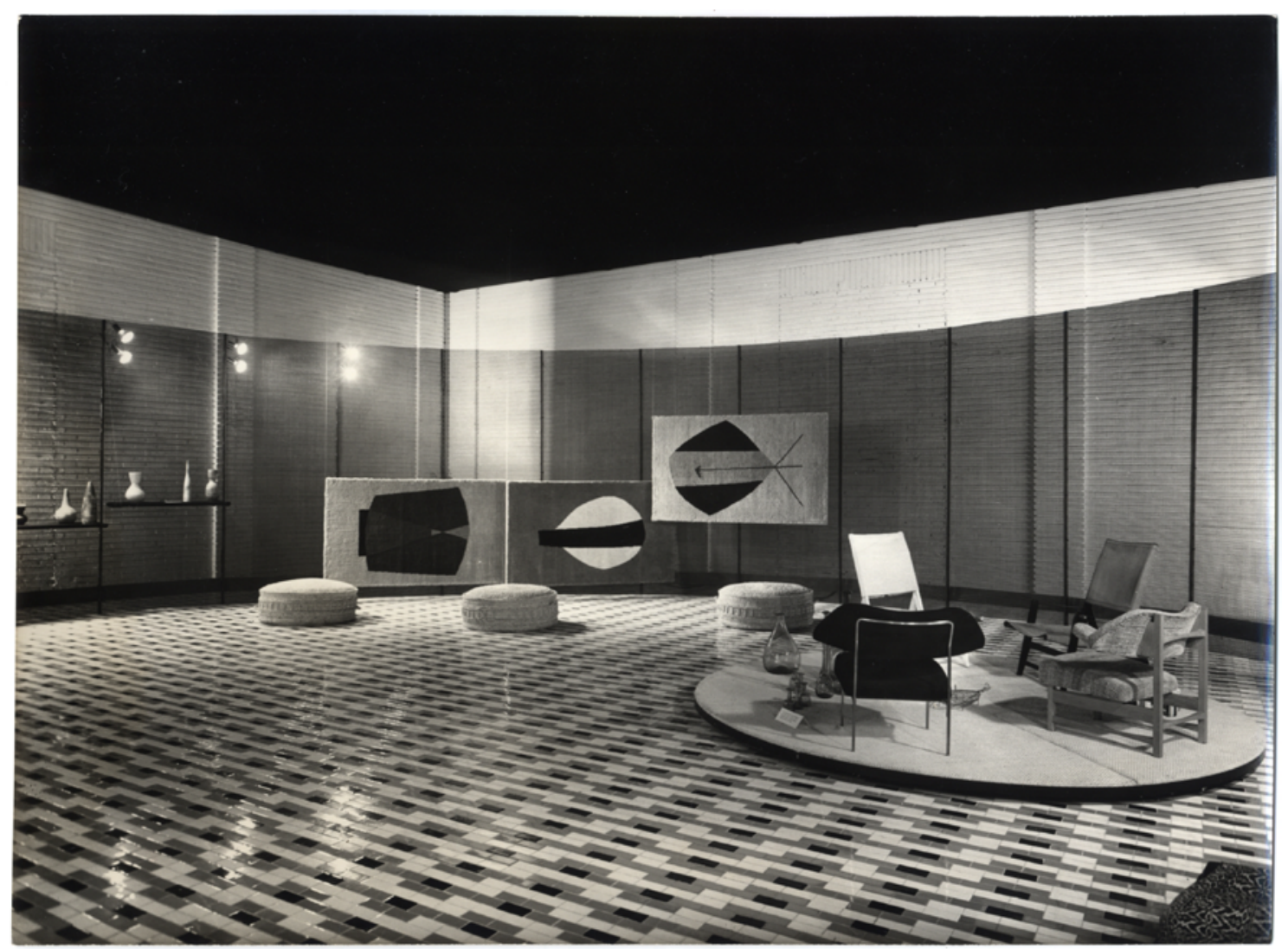

Fig.6. Pabellón español de la XI Trienal de Milán (1957), diseño de Francisco Javier Carvajal y José María de Paredes. (C) Triennale Milano - Archivio Fotográfico.

No muchos elementos en verdad, solo con ellos Carvajal y García Paredes han logrado que la participación de España a la XI Trienal de Milán sea tan valiosa como lo fue en las dos precedentes, en las que consiguió el máximo galardón. ${ }^{11}$

Un mes antes, en diciembre, Joaquín Vaquero Turcios firmaba como "alumno de arquitectura" una crónica sobre la "crisis en la Trienal" publicada en la Revista Nacional de Arquitectura (en adelante RNA). El texto, escrito en simultaneo con la inauguración, aunque publicado más tarde, se hacía eco del ambiente de crisis de orientación que dominaba el certamen. Pese a todo, resaltaba el pabellón finlandés de Timo Sarpaneva y el pabellón español. De este último resaltaba: 
Una tensa emoción dramática y un gran carácter nacional, sugerido con elementos industriales, pero que adquieren personalidad poética -la frescura del azulejo, la misteriosa transparencia de la malla de hierro, la claridad fosforescente de la cal-, hacen que este pabellón sea inconfundible y el único que de pura decoración pasa a tener categoría de arquitectura, con un "tema" espacial resuelto con la mayor simplicidad y la mayor intensidad. ${ }^{12}$

La yuxtaposición de obras de arte contemporáneo, artesanías populares y artes aplicadas con vocación de actualidad subsumidas en una instalación de inequívoca modernidad arquitectónica fueron la combinación que permitió representar dignamente y con elogio a España en las tres ediciones de la década. Fue una salida airosa para un país que, en aquellos años, padecía un manifiesto retraso industrial y apenas remontaba de su aislamiento cultural. Para sortear la dificultad de mostrar novedades competitivas en un marco volcado a la actualidad del diseño industrial, el montaje apostaba más por una idea ambiental de conjunto. Así la concebía García de Paredes:

La Trienal es más que una exposición, una invención escénica, una composición arquitectónica que recibe su forma y su ritmo de los artistas, de los objetos, de la materia, de los colores, de la división de los espacios y de los volúmenes. La Trienal no es, por tanto, un solemne y estático museo, sino algo absolutamente vivo y mutable, en que todos los países concurrentes se esfuerzan en una total y deportiva emulación para ofrecer lo más notable de su producción en el campo de las artes aplicadas y del industrial design. ${ }^{13}$

A pesar del indudable éxito de derivar la atención a la percepción del conjunto, ya en ediciones anteriores algunos elogios podían contener, soterrada, una crítica. La crónica de la RNA del pabellón de 1954 de MoGaMo citaba una alabanza de Gio Ponti en la revista Domus algo ambigua: "España ha resuelto con gran elegancia su sección en la Trienal. No ha dado una imagen del arte decorativo español, pero sí ha dado una imagen de España". ${ }^{14}$ Las sospechas ya habían aparecido en la presentación de 1951. Después de elogiar la labor de Coderch, Vaqueros Turcios se lamentaba de la sobrerepresentación de cantaros y botijos y de la ausencia de arte aplicado verdaderamente contemporáneo: "España acude a las Exposiciones Internacionales con elementos preciosos, nadie lo duda, pero que acusan un duro contraste de espíritu de época al enfrentarse con los envíos de los demás países". ${ }^{15}$

Aquellos "peros" venían dados porque el efectismo de los pabellones no podía ocultar completamente los trueques y permutas, fueran con la artesanía popular o con las obras artísticas. Los inusualmente modernos montajes arquitectónicos de los pabellones españoles, por muy deslumbrantes que fueran, tenían una carencia evidente que se atisbaba ni bien se comparaban con el tipo de productos más sobresalientes de la Trienal. El pabellón de Carvajal y García de Paredes, conscientes de ello, intentó eludir aquellas críticas con una representación más generosa de objetos decorativos actuales, renunciando a las piezas exclusivamente artísticas y aminorando la exhibición de piezas de artesanía 
popular. Era un espacio mucho mayor que el destinado a los pabellones de anteriores selecciones y la estrategia expositiva jugó a seleccionar unas pocas, pero bien dispuestas piezas que contribuyeran al efecto global.

El juicio más severo llegó con un artículo de Oriol Bohigas en el número de diciembre-enero del semanario Revista. El título ya indicaba por donde podían ir las cosas: "El diseño industrial en la XI Trienal de Milán”. Luego de hacer una evaluación crítica de la trayectoria de la Trienal y de la XI edición, Bohigas procedía a un balance de la participación española. Sin restar mérito alguno a los arquitectos responsables del pabellón denunciaba los problemas que éste tenía con sus contenidos.

Este año, Javier Carvajal y J. M. García de Paredes han pensado que era mejor no hacer trampas, que no se podía repetir la jugada de exponer esculturas o pinturas en un certamen de artes industriales. Y han resuelto el problema por el camino de en medio: no exponer casi nada. El pabellón español es la mejor instalación de la Trienal, pero es, sin duda, el de peor contenido. ${ }^{16}$

De la hoguera a la que lanzaba, una tras otra, las piezas exhibidas solo se salvaba las cerámicas de Cumella y "una silla de Coderch, Correa, Milá". Ni las maletas "de medio pelo" de Loewe, ni los tapices de De la Sota o las telas de Clara Szabó que tilda de objetos "amanerados" merecían otra consideración. La razón, empero, se encuentra cuando se confirma su adhesión a la idea de que "las antiguas artes decorativas habían casi desaparecido para dar paso a ese Industrial Design cada vez más fecundo" que "ocupaba la mayor parte de secciones extranjeras" además de las italianas. ${ }^{17}$ Para el autor, a pesar de la intención, los contenidos del pabellón, que alcanzaban por fin las artes industriales y aplicadas, ya llegaban tarde respecto al diseño industrial.

Aunque Bohigas se abstenía de mencionar la butaca Toro, resulta evidente que Toro y Barceloneta, aunque no fueran novedades, constituían la representación más nítida de lo que podía entenderse por "diseño industrial"; o, tal vez dicho con mayor precisión, de lo que era un diseño protoindustrial que podía aspirar a su industrialización.

La transmisión de una imagen de España que entroncara la modernidad con la tradición fue siempre la prioridad en las presentaciones españolas de la Trienal. Dicho planteamiento no indica que la selección de objetos no estuviera guiada por un alto valor de representación. Al contrario, cada pieza resultaba singular y apropiada en la construcción del concepto que se pretendía, como si se tratara de vocablos de un sintagma. Sobre ello había plena conciencia, tal y como se confirma en estas explicaciones de García de Paredes:

El tema central en que se inspiró la participación española a la Trienal fue la continuidad de una tradición que encuentra en sí misma la fuerza para una renovación actualizada. (..) En la selección de las obras destinadas a la exposición se procuró pues demostrar cómo a través de una realización que se desarrolla en la línea de lo tradicional, puede llegarse a obras absolutamente actuales. ${ }^{18}$ 
Un motivo bastante obvio apunta que la selección de las butacas Toro resultaba muy coherente con la intención de reforzar la comedida figuración del ruedo taurino que inspiraba el diseño general. El toro también era el motivo de algunas piezas del pabellón del 51 y estaba sugerido en el juego de sombras creado por MoGaMo en el 54 con las esculturas de Chillida. Ya en aquellos años anteriores a la ola turística de los 60, el toro pasó a ser la imagen más sintética de la españolidad, fuera en su versión más folclórica y pintoresca como en su versión más trágica e intelectualizada. Esta última era sin duda a la que se apelaba lorquianamente en el pabellón. Sin embargo, al mismo tiempo, no se quería renunciar a esa dimensión más suave y hedonista de España que aportaba la idea de mediterraneidad, tan presente en la instalación de Coderch seis años antes. Ésta se representaba más directamente con los azulejos del pavimento o con un conjunto de recipientes de vidrio mallorquín dispuestos cerca de una tumbona como la Barceloneta.

En un informe interno de trabajo, Carvajal, explicando el montaje, insistía en la polaridad entre los azulejos, que remiten al "recinto mediterráneo luminoso y fresco" y "la trágica fuerza" de la dureza industrial del cercado metálico como componentes del "mágico circulo de nuestro ruedo Ibérico". Dichos argumentos podrían extrapolarse a aquello que se pretendía poniendo de frente los asientos Toro y Barceloneta. ${ }^{19}$ Tal juego de contrarios entre ambas poéticas, la del áspero fatalismo castizo de la tauromaquia y la de la mediterránea y dorsiana oceanografía del tedio, podían perfectamente ser los motivos de tal selección.

Hasta qué punto se perseguía un efecto estético y comunicativo de estas ideas lo constatamos no solo con la selección de objetos que viajaron a Milán sino, de entre ellos, la elección de los que terminarían expuestos y los que no. ${ }^{20}$ El proyecto arquitectónico indicaba una disposición general, pero luego quedaba por hacer una labor museográfica o escaparatista de colocación de las piezas in situ que determinaba algunos descartes. En el caso del pabellón de 1957 se descartaron bastantes piezas enviadas a Milán. La más significativa, en relación con el tema que tratamos, es la de dos ejemplares de la silla Parábola de Rolaco (fig. 7). Este diseño de 1953 de Luis y Javier Feduchi, que aparece en la relación de objetos enviados, no se expuso; al igual que una mesa "haciendo juego" y un frigorífico, todos de la misma firma Rolaco. ${ }^{21}$

Entre todos los objetos presentados, los muebles representaban la muestra más locuaz de un diseño de arquitectos en España que había ido abriendo paso, con dificultad, a la idea de diseño industrial en modesto parangón con el caso italiano o finlandés. Lo cierto es que ya en 1957 se encontraban algunos buenos ejemplos que mostrar, como, con todo mérito, era el caso de la mencionada silla Parábola. Aunque desconozcamos a ciencia cierta los porqués del descarte, resulta bastante evidente que la peana grande, destinada en el plano de Carbajal a "Muebles", no tenía suficiente capacidad para albergar otro par de sillas (fig. 8 y 9). Es seguro que se consideraría que la concepción escenográfica del pabellón exigía no abigarrarlo de piezas, pues ello hubiera desdibujado la evocación del coso taurino y el carácter sucinto de la idea. Acaso, también, el aspecto más industrial de la silla de Feducchi -por no decir del frigorífico- casara menos con el montaje. De hecho, la silla Parábola, ideada para los interiores del 
Hotel Hilton de Madrid (1953), respondía a una inspiración norteamericana que tampoco acordaba con la idea general.

En la ya mencionada Nota Informativa de mayo de 1957 para el MAE, Carvajal, con semejantes argumentos a los que ya hemos leído de García de Paredes, justificaba la instalación con las siguientes palabras:

España, en un periodo inicial de transformación industrial y en un esfuerzo por la creación de un mundo nuevo y más humano, centra su aportación en la idea de la expresión de los conceptos estéticos actuales, a través de los materiales tradicionales.

Y la obra de los artistas y artesanos que concurren, muestra asimismo cómo a través de una obra que se mueve dentro de los cauces de la tradición artesana es posible llegar a una obra actual enlazada con la tradición. ${ }^{22}$

Todo lo cual nos remite a una tensión permanente entre artesanía y diseño industrial, tradición y modernidad, anonimato y autoría, que afrontaban los pabellones españoles en la Trienal, y el del 57 en particular. También nos habla de los equilibrios con los que lidiaban los responsables del pabellón. Tal era la problemática de encarar la modernidad en un entorno productivo no modernizado y en un ambiente cultural que tampoco se mostraba proclive a tales desafíos.

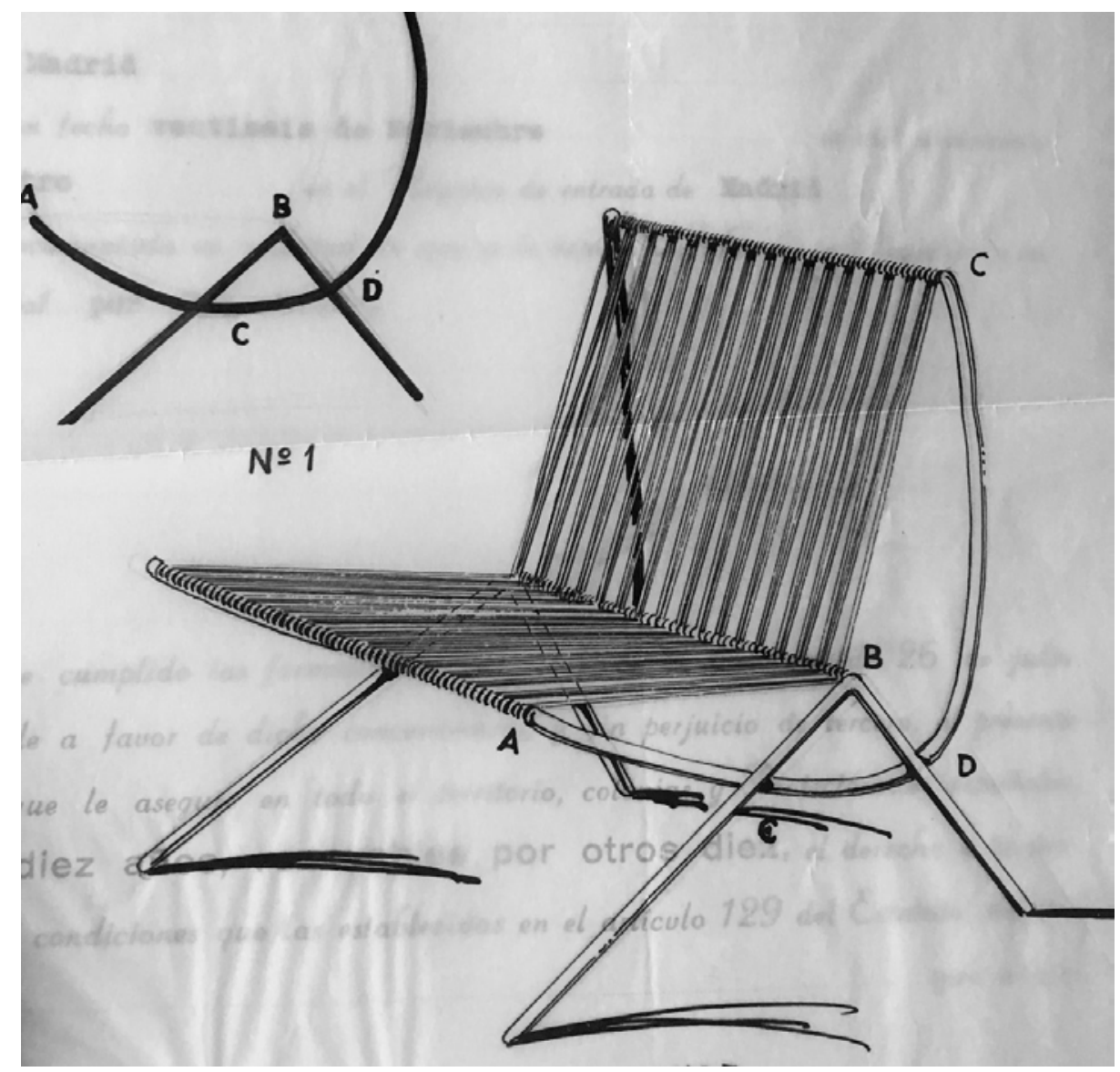

Fig.7. Imagen de la Memoria del Modelo Industrial de la silla Parábola diseñada por Luis M. Feduchi en colaboración con su hijo Javier. Archivo Rolaco. Museo Nacional de Artes Decorativas. 

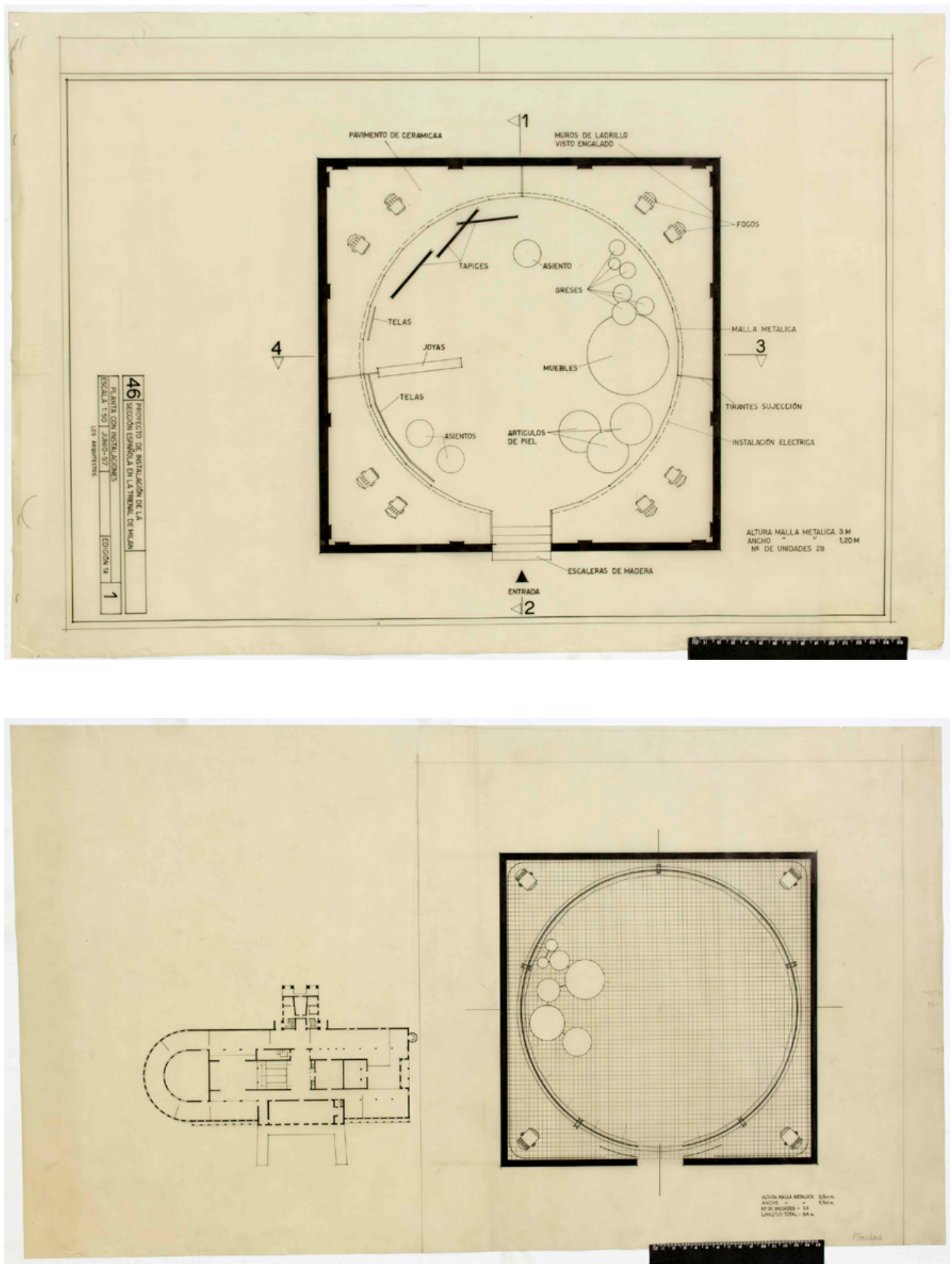

Figs.8 y 9. Planos del pabellón español de 1957. Autores Carvajal-García de Paredes. Fondo Personal de Javier Carvajal Imágenes cedidas por el Archivo General, Universidad de Navarra. 


\section{1957 en la historia del diseño en España}

Si proseguimos nuestro esfuerzo de contextualización, aún encontraremos nuevas pistas para revelar un sentido más completo de los muebles presentados en Milán. 1957 es un año significativo en la historia del diseño industrial por lo que aporta de nuevas iniciativas y avances en su concepto y práctica profesional. Además, se dan una serie de correspondencias entre las presentaciones españolas en la Trienal y la progresión del movimiento en pro del diseño en España que no siempre han sido detectadas o subrayadas como se debía. Y algunas de ellas conciernen de alguna manera a los dos muebles referidos.

En España, el camino de la modernidad a través del diseño en los años 50 tuvo dos epicentros destacados e interconectados en Madrid y Barcelona. En Madrid el liderazgo lo ejerció la Revista Nacional de Arquitectura (RNA) dirigida por Carlos de Miguel. Desde que tomó su dirección en el verano de 1948, junto a la presentación de obras de arquitectura, la revista empezó a mostrar interés por temas de artesanía, arte decorativo y mobiliario. Dicho interés se vería reforzado a partir de 1951 precisamente con las informaciones dedicadas a la IX Trienal y al pabellón diseñado por Coderch. Ante una dinámica que venía del aislacionismo cultural más estricto, la $R N A$ emprendió la tarea de dar a conocer lo que ocurría en el exterior -fuera a través de proyectos, autores o eventos- y fue inclinando su selección de reportajes de proyectos locales en un sentido de renovación contemporánea. Por otra parte, mediante las reuniones que organizó a partir de 1951 -las Sesiones de Crítica de Arquitectura- y la publicación de aquellos debates, logro conectar y aunar voluntades entorno a la idea de regeneración artística y arquitectónica. A lo largo de la década, se dedicaron artículos al diseño industrial, un número monográfico e incluso se organizó un premio. De Miguel fue el alma y el promotor directo de muchas de aquellas iniciativas.

En Barcelona el núcleo en el que germinó la idea de diseño industrial fue el Grup R. Entre sus miembros, Coderch ejerció el papel de referente más internacional, pero Antoni de Moragas y Oriol Bohigas fueron los más activos y volcados a impulsar el diseño. Hay que observar que el grupo se constituyó a finales de agosto de 1951, con la IX Trienal inaugurada desde mayo y Coderch acariciando su reconocimiento. Desde aquel momento, la conexión de Barcelona con Milán fue un factor importante para el devenir de la arquitectura y el diseño en Cataluña; lo que iba más allá de que Coderch pasara a actuar como corresponsal en España de la revista Domus.

Pero retomemos el pulso de 1957. La undécima Trienal se inauguró 27 julio 1957 y se clausuró el 4 noviembre. Unos meses antes, en abril del mismo año, arquitectos vinculados al Grup R liderados por Antoni de Moragas, y afines como Alexandre Cirici Pellecer, se reunieron en una sesión de trabajo con Gio Ponti en un restaurante barcelonés. Al encuentro también asistieron algunos emprendedores del comercio y la industria. Las palabras de Ponti exhortaron a organizarse y promocionar el diseño industrial. De resultas de aquel encuentro se sucedieron reuniones para crear una asociación que promocionara el diseño. De ahí surgió el ánimo de crear el IDIB, Instituto del Diseño lndustrial de 
Barcelona. Cirici Pellicer redactó el manifiesto. La noticia y el mismo manifiesto aparecerían publicados el mes de julio, poco antes de inaugurarse la Trienal. ${ }^{23}$

Casi al unísono se fraguó otra iniciativa: la creación en Madrid del SEDI, Sociedad Española de Diseño Industrial, promovida por De Miguel, Feduchi y Carvajal, a la que se sumarían otros miembros como José Luis Sánchez o Javier Feduchi, y más tarde José María Cruz Novillo y José María de Labra. ${ }^{24}$ No cabe decir que el vínculo con la Trienal del 57 resulta evidente puesto que Carvajal se estaba ocupando, justo en aquel momento, del pabellón español pronto a inaugurarse. Se respiraba un cierto ambiente de euforia respecto a esos temas. El afán de organización asociativa del diseño debía ser general pues el 29 de junio de aquel año se constituiría oficialmente en Londres el ICSID, International Council of Societies of Industrial Design, cuya necesidad ya se había planteado en 1953, durante el Congreso Internacional del Instituto sobre Estética Industrial que sirvió de base documental para el monográfico de la RNA de 1955.

La iniciativa de Barcelona y la de Madrid estaban entrelazadas y tenían un mismo origen como lo constata la crónica de De Miguel. En el número de mayo de 1957, el director de la revista anunciaba la creación de una Asociación Española de Diseño Industrial en un artículo de seis páginas en el que presentaba la reunión de Barcelona, transcribían las palabras de Ponti y resumía los debates. El discurso de Ponti animaba a seguir el modelo italiano; es decir, crear una asociación de profesionales siguiendo el modelo del ADI italiano, instituir unos premios similares al Compasso d'Oro, promover la concienciación empresarial y ganarse el aval gubernamental. Concretaba estos logros hablando de la Trienal de Milán como gran demostración propagandística y escaparate para todo lo anterior. La crónica afirma que después de un intercambio de impresiones se decidió constituir una asociación para impulsar tal programa y confirma la presencia en dicho encuentro de Carvajal y De Miguel, autor del artículo, que asumieron trasladar dicha iniciativa a Madrid:

Después de un cambio de impresiones entre los asistentes, se decidió la constitución de un Comité formado por los arquitectos Bohigas, Moragas y Monguió y los industriales Capdevila, Marinel lo y Passola, que han de elaborar un programa que será expuesto en la próxima reunión.

Paralelamente a esta actuación en Barcelona, y como quiera que, por otros motivos, estuvieron presentes los arquitectos del Colegio de Madrid, Carvajal y De Miguel, se decidió que éstos intentaran la creación de un organismo similar en la capital, para que, en reuniones sucesivas y conjuntas en Madrid y Barcelona, se llegue, con el resto del país, a la formación de la Agrupación Española del Diseño Industrial. ${ }^{25}$

No es momento de extenderse más en aquel acontecimiento, pero era necesario dar una idea más cabal del momento en el que se presentaba el Pabellón y las sillas en Milán. Para ello resulta igualmente conveniente corregir aquellos relatos que presentan tales iniciativas como un conjunto de hechos fortuitos y desvinculados. 
Para lo que concierne más directamente a nuestro tema resulta interesante observar que, en cierta manera, los dos pares de asientos también encarnaban la representación de los dos núcleos mencionados. Se presentaban piezas de diseños de los dos arquitectos de mayor proyección internacional y los que mejor ostentaban la representación del despertar de la modernidad en Madrid y en Barcelona. Lo que es claro en el caso de Fisac y su butaca Toro requiere una aclaración para la autoría de la tumbona Barceloneta, pues a aquellos efectos se atribuía a Coderch o al Estudio Coderch. ${ }^{26}$ Recordemos que Correa y Milá apenas habían empezado a publicar sus obras, como la Casa Villavecchia de Cadaqués en 1955, una modesta reforma que, no obstante, devendrá notable y será el inicio de un fructífero recorrido. Así pues, las Toro y las Barceloneta, por el nombre que las conocemos hoy, podían perfectamente representar salomónicamente Fisac y Coderch, al tiempo que sugerir los núcleos de Madrid y Barcelona.

\section{Diseño y artesanía en los 50, ideas y producciones}

Si se insiste en este texto en atribuir ciertas cualidades prosopopéyicas a los asientos, convendría desarrollar algo más sobre el tipo de diseño que personificaban. Al respecto, la toma de conciencia sobre lo que significara el diseño industrial y su evolución debe relacionarse con el papel del arquitecto, el debate sobre la artesanía y la estética de los bienes de consumo, así como con las peculiaridades de la estructura productiva española.

Como se decía al inicio de este artículo, el punto de arranque del interés por el diseño de muebles en aquella etapa puede buscarse en los muebles de arquitectos; o, mejor dicho, en el propósito de los arquitectos adscritos a la modernidad por proyectar el diseño completo de sus obras. Tanto en el caso de Fisac como en el de Coderch, Correa y Milá la habitabilidad de los espacios de sus arquitecturas fueron considerados un cometido fundamental del proyecto que los comprometía hasta la resolución del menor detalle. A Fisac le inspiraba el ejemplo de Asplund o Aalto, entre otros a los que cita. Coderch tomó ejemplo de lo aprendido en la revista AC, Documentos de actividad contemporánea, del fervor de Gaudí y de la modernidad de Ponti, principalmente.

En estas actitudes prevaleció un convencimiento sobre la misión del arquitecto y un horizonte estético que abogaba por superar el desconcierto del gusto y la falta de buen criterio; por lo que Fisac preguntaba:

¿Quién debe hacer los muebles? Si, como debe ser, y como es por ahí fuera, es labor de los arquitectos, ¿podemos consentir los arquitectos que se siga dando vueltas, cada vez más desafortunadamente, a esos estilos históricos, histéricos, coloniales e isabelinos? ${ }^{27}$

Está claro que principios de los 50 no se razonaba en términos de diseño "industrial". Lo que primaba era, por un lado, conceptos estéticos de gusto y, por el otro, las razones de la lógica proyectual en relación con la construcción y los usos. Efectivamente, aquellos primeros diseños nacían destinados a una reproducción de unos pocos ejemplares y apenas se pensaba en su comercialización. 
Se trataba de piezas para amueblar un proyecto concreto, fabricadas por talleres de escala modesta en series de pocos ejemplares, que luego se transfirieron a otros nuevos proyectos de los mismos autores o de colegas allegados. Al menos estos fueron los primerísimos pasos, tanto para los modelos Toro como para los Barceloneta y otros tantos diseños.

En verdad, son diseños que eran concebidos desde una explícita oposición al mecanicismo racionalista y sin tentación alguna de "estilo" internacional. Por el contrario, buscaban emparentarse con el ideal artesano y el acervo local, lo que por otra parte vino a concordar con la orientación organicista y regionalista en arquitectura y diseño. Pero en el caso español cabe decir que la reivindicación de la artesanía era coincidente con un modelo productivo débilmente industrializado, igual que la insistencia en la tradición coincidía con un ambiente cultural reacio al capitalismo liberal y urbano, como, a fin de cuentas, lo era un franquismo ideologizado de corte falangista o tradicionalista. Ruralismo, tradicionalismo y nacionalismo formaban parte del discurso oficial. ${ }^{28}$

No obstante, para arquitectos como Fisac y Coderch, la artesanía y la tradición no era un punto de llegada sino un punto de partida. Los arquitectos de esta segunda modernidad contemplaban la relación entre artesanía y diseño como una oportunidad de abrirse al exterior con una voz propia. De ahí la fascinación por el modelo finlandés que alimentaba la aspiración a una modernidad inequívocamente española. Se trataba, entonces, de reivindicar el saber artesano y los oficios como modelo productivo característico, pero bajo la dirección de los artistas y arquitectos capaces de reinterpretar la tradición popular y emparejarla con el espíritu de la contemporaneidad.

Esta vía española al diseño industrial seguía siendo la que reclamaba desde las páginas de la $R N A$ en la crónica que anunciaba la inminente creación de una asociación de diseño industrial en mayo de 1957 (fig. 10 y 11). En relación con la imagen de un porrón y una frasca, el editorialista (De Miguel) comentaba lo siguiente:

(...) dos estupendas creaciones del genio artesano español. Este es el camino, el auténtico camino tradicional. No, naturalmente, repetir estas piezas, sino crear los nuevos utensilios para las nuevas necesidades al modo genuinamente español. No copiar con la mirada vuelta al tiempo pasado, ni tampoco, absolutamente tampoco, con la vista fija en el actualísimo extranjero distante. ${ }^{29}$

Ese era el discurso dominante en los pabellones españoles de la Trienal, que, si en ediciones anteriores se vislumbraba como una potencialidad, en la de 1957 se mostraba, pese a lo que dijera Bohigas, con mayor intención.

Sin embargo, edificar el nuevo diseño en los cimientos de la artesanía como referente estético de un diseño nacional resultó plausible solo durante un tiempo. Más allá del efectivo déficit industrial o de los residuos autárquicos, se esgrimían premisas culturales. El paradigma artesano se veía como una condición necesaria para contrarrestar los efectos deshumanizadores de la estandarización y la disolución de las esencias culturales en unas dinámicas de mercado enajenantes. Aquel "actualísimo extranjero distante" del que se hablaba en la 
crónica de la $R N A$. Pero la idealización de la estructura productiva del artesanado y la inconsistencia de la red comercial, por no hablar de las reticencias de un gusto mayoritariamente conservador, hacían cada vez más patente la debilidad de aquel proyecto que dominó la década. Ciertamente, emular el modelo finlandés y escandinavo despertó muchas expectativas, principalmente en el núcleo madrileño, aunque a la postre no pasó de ser una utopía.
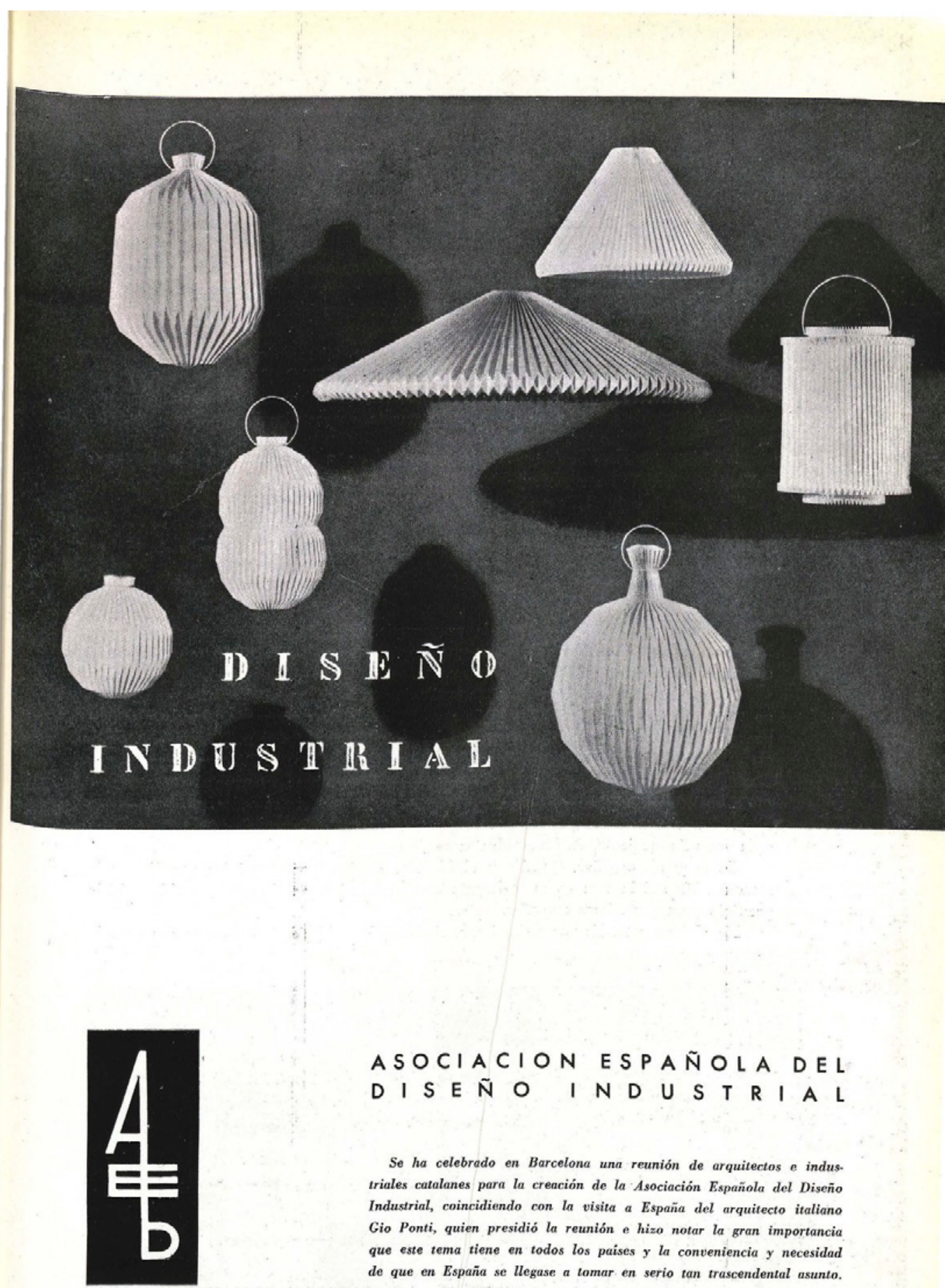

ASOCIACION ESPAÑOLA DEL $D$ I S E N O I N D U S T R I A L

Se ha celebrado en Barcelona una reunión de arquitectos a indus. triales catalanes para la creación de la Asociación Española del Diseño Industrial, coincidiendo con la visita a España del arquitecto italiano Gio Ponti, quien presidió la reunión e hizo notar la gran importancia que este tema tiene en todos los paises y la conveniencia y necesidad de que en España se llegase a tomar en serio tan trascendental asunto. 
Después de un cambio de impresiones entre los asistentes, se decidió la constitución de un Comité, formado por los arquitectos Bohigas, Moragas y Monguio y los industriales Capdevila, Marinello y Passola, que han de elaborar un programa que será expuesto en una próxima reunión.

Paralelamente a esta actuación en Barcelona, y como quiera que, por otros motivos, estuvieron presentes los arquitectos del Colegio de Madrid, Carvajal y De Miguel, se decidio que éstos intentaran la creación de un organismo similar en la capital, para que, en reuniones sucesivas y conjuntas de Madrid y Barcelona, se llegue, con el resto del pais, a la formación de la Agrupación Española del Diseño Industrial.

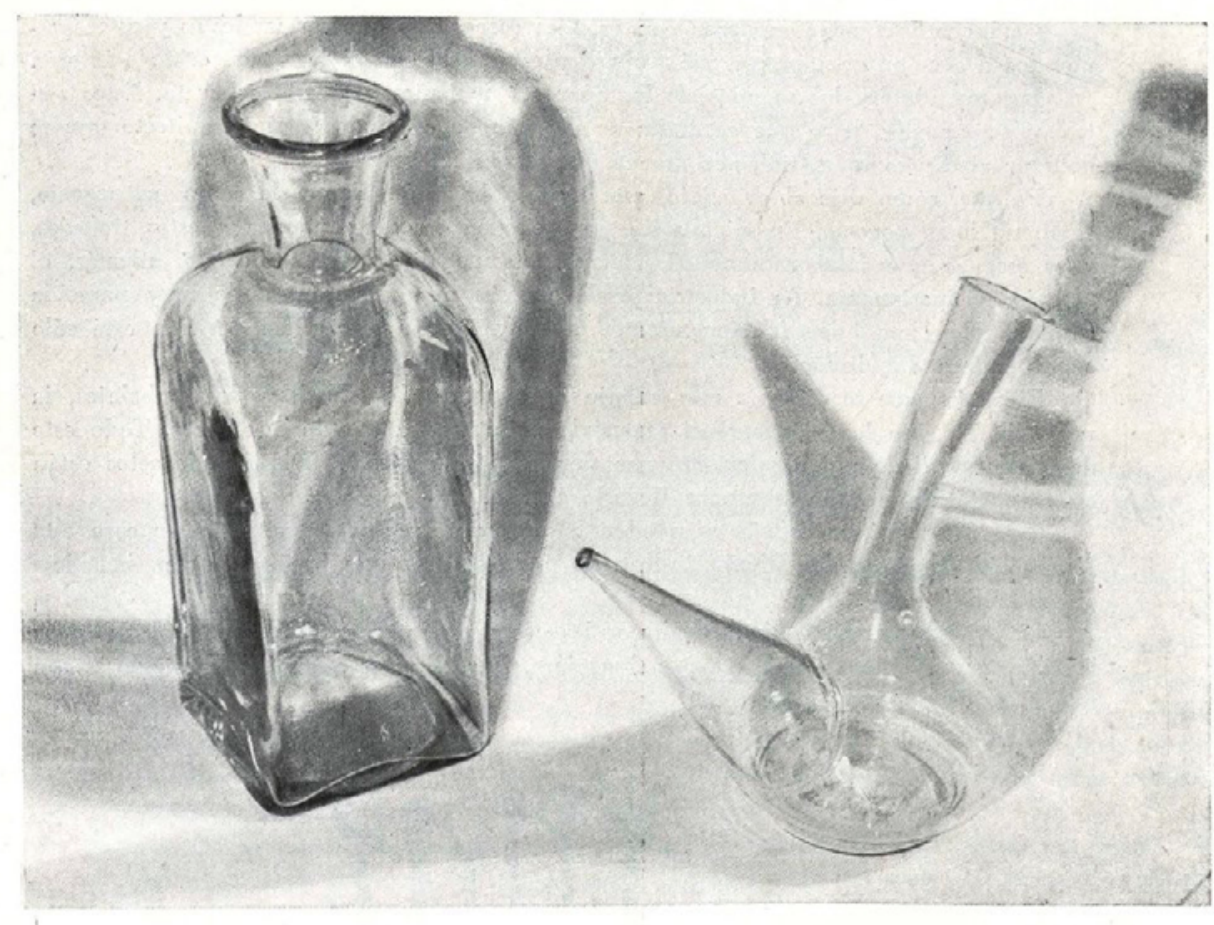

El "porrón" y la "frasca", dos estupendas creaciones del genio artesano español. Este es el camino, el auténtico camino tradicional. No, naturalmente, repetir estas piezas, sino crear los nuevos utensilios para las nuevas necesidades al modo genui. namente español. No copiar con la mirada vuelta al tiempo pasado ni tampoco, absolutamente tampoco, con la vista fija en el actualisimo extranjero distante.

Hizo hincapié Ponti en la absoluta necesidad de la propaganda, en lo que al diseño industrial respecta. $Y$, siguiendo su consejo, hemos dado en estas páginas publicidad a sus palabras, que deben ser un acicate para todos nosotros.

Este asunto del Diseño Industrial es una de nuestras más queridas preocupaciones. Por ello, en abril de 1955 dedicamos un número de esta RevisTA a este tema, y el año 1956 organizamos, lo mejor que pudimos, un Concurso de Diseño Industrial en Madrid. La eficaz colaboración que recibimos por parte de tres industriales de Madrid y por los concursantes, qu e trabajaron, ciertamente, mucho y muy bien, hizo que el Concurso no estuviera del todo mal. Con los trabajos presentados hicimos una Exposición, y después un número de esta Revista. Teníamos la intención de celebrar una posterior Exposición con las obras realizadas de acuerdo con los

36

Figs.10 y 11. Páginas del artículo "Diseño industrial: Asociación Española del Diseño Industrial" RNA, nº 185, mayo 1957, pág. 33 y 36. 
A lo largo de toda la década, ese mundo de conceptos se había movido en un haz de contradicciones. La producción artesana, por ejemplo, resultaba poco compatible con las necesidades de equipamiento de los programas sociales de vivienda. Fisac y Coderch, como Fernández del Amo, Alejandro de la Sota, Francisco de Asís Cabrero y otros, trabajaron para la Obra Sindical del Hogar. Y de allí provenía un estímulo para buscar un tipo de mobiliario que resolviera, con dignidad cultural, el abaratamiento de costes que el tipo de promoción exigía. Se dieron algunas iniciativas en este sentido lideradas por el Instituto Nacional de la Vivienda. Así, el proyecto de mobiliario presentado por Antoni de Moragas al Concurso Pro Dignificación del Hogar Popular en 1954 es un buen ejemplo de cómo, desde una posición en favor del diseño industrial, se abordaba los problemas de la estandarización y los nuevos materiales.

Al mismo tiempo, a mediados de la década, gracias a la moderada liberalización económica, se había experimentado un crecimiento del volumen de renta. También aumentaron considerablemente las importaciones y la producción industrial se recuperaba con rapidez del estancamiento de la década anterior. Todo ello movilizaba el mercado y resultaba esperanzador para un mejor acomodo de la idea de diseño industrial. La apuesta por la serie y la estandarización de modelos se abría paso entre quienes entendían que llegaba el momento de comprometerse con la estética de la producción industrial. También la silla Parábola de Feduchi de 1953 resulta un buen ejemplo de esta evolución en la medida que, en la línea de Rolaco, ensayaba un asiento que no respondía a la manufactura tradicional de carpintería y tapizado.

Por su parte, el grupo barcelonés tenía igual estima por lo que representaba la arquitectura y el diseño de Finlandia, pero le movía un sentido más pragmático. El tejido industrial y comercial catalán permitía pensar con mayor verisimilitud en el referente italiano. Barcelona estaba lejos de poder parangonarse con Milán en términos de diseño industrial, pero en tal asimilación puso su mayor empeño. Por esta razón, en un artículo de 1954 en Cuadernos de Arquitectura, donde Moragas exponía los argumentos de la segunda exposición del Grup $\mathrm{R}$ se soltaba lastre de la artesanía. El título de la muestra en las Galerías Layetanas de Barcelona era, recordémoslo, "Industria y arquitectura" (fig. 12). Moragas advertía que "no es posible proyectar cada día y para cada obra la carpintería metálica, las puertas, las lámparas y las sillas" y proponía asumir lo que tal planteamiento conllevaba:

Ya sabemos que todo esto llevaría a la desaparición del artesanado. Pero ¿no está desapareciendo de todos los órdenes de la vida? Creemos que es posible la sustitución del artesanado por la estandarización sin perder el sentido humano de las cosas.

Y ¿no será mejor un artesanado de dirección que un artesanado de ejecución? Aquí se abre un campo de acción inmenso al arquitecto, o sea su intervención en la gestación de los elementos industriales. ${ }^{30}$

En definitiva, se abogaba por la arquitectura como arte social, se proponía aceptar el reto de la industria y se aspiraba a que el papel del arquitecto como diseñador preservara la naturaleza cultural y humana de los nuevos productos. 


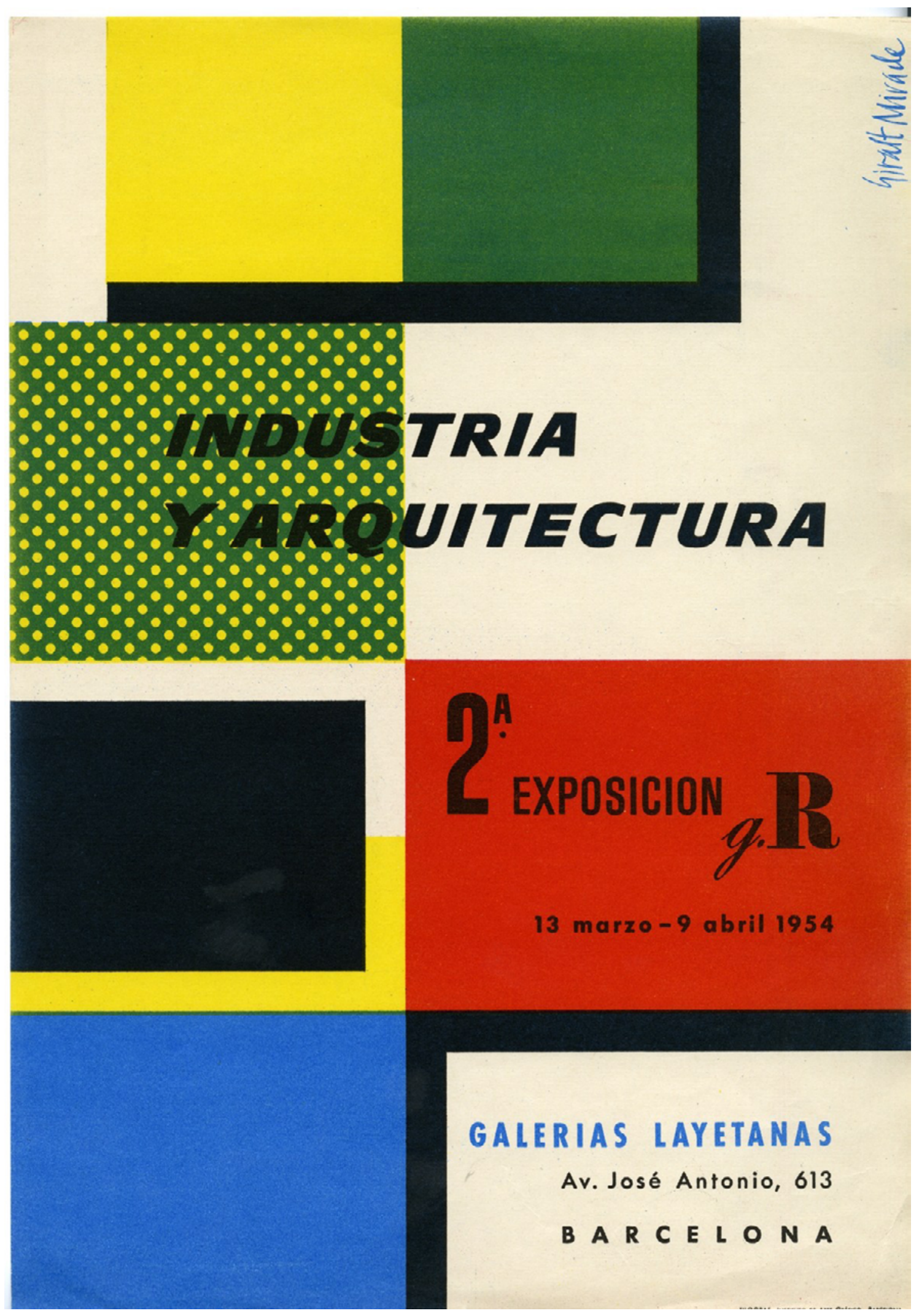

Fig.12. Cartel de la $2^{\mathrm{a}}$ exposición del Grup R. Industria y arquitectura en las Galerías Layetanas, 1954. Diseño gráfico de Ricard Giralt Miracle. 
Si el debate de ideas resulta ilustrativo del momento, también lo es un mayor conocimiento de la realidad productiva y comercial que nos proveen los ejemplos de los asientos Toro y Barceloneta. Los primeros ejemplares de la butaca de Fisac se deben al Taller de Carpintería La Navarra de Madrid, empresa fundada en 1941. De hecho, dicho taller realizó desde 1942 la mayor parte de los trabajos de carpintería de las obras de este autor, así como los muebles para el CSIC y otros proyectos. ${ }^{31}$ Sus propietarios, los hermanos Lagarreta fueron quienes le encargaron el primer proyecto residencial en Ortigosa del Monte (Segovia), en el que también estaba presente el asiento que nos ocupa. Los encargos que proveía Fisac hicieron crecer el taller que se fue especializando en obras singulares. Hasta donde sabemos, los ejemplares de la butaca Toro fueron fabricados por dicho taller, aunque a partir de 1959 se incorporarían al catálogo de Darro, la empresa que los comercializaría en la década siguiente. ${ }^{32}$

Algo parecido ocurre con la tumbona Barceloneta. El fabricante del diseño de Correa y Milá fueron los talleres Llambí. Éste era un obrador de carpintería familiar del barrio de La Sagrera de Barcelona que tenía su origen a principios de siglo XX y que prosperó en los años 20 y 30 cuando paso a identificarse como Taller Mecánico de Carpintería Pedro Llambí. Coderch entró en contacto con ellos en el segundo lustro de los 40 como fabricantes de sus diseños de carpinterías y muebles. Llambí se encargó de obras como la Oficina de turismo de Sitges (1946) o la Casa Nogués (1947), en la misma población costera. En ambas colaboraciones se diseñaron elementos que luego serían importantes para la IX Trienal de 1951: las sillas y mesa de la oficina y las persianas brise-soleil de la vivienda; unas estuvieron expuestas en Milán y las persianas inspirarían el display para las fotografías de arquitectura de Gaudí y de arquitectura popular ibicenca.

El recorrido de la silla Llambí fue limitado en el tiempo, a pesar de haber obtenido la Medalla de Oro en la IX Trienal. Coderch la incorporó en algunas de sus obras, como en el mismo piso-muestra de la Barceloneta. Pero fue un modelo que pronto sustituyó por la Superleggera diseñada por Ponti, que fue la silla que, amuebló algunos de sus interiores a partir de 1955. De hecho, la Llambí se inscribía en una búsqueda de estilización de las sillas de enea tradicionales que persiguieron distintos arquitectos y que, se podría decir, culminaría en la Superleggera. ${ }^{33}$ Tal substitución se explica, además, porque a partir de 1955 Llambí obtuvo la licencia para fabricar la Superleggera, con toda seguridad gracias a la mediación de Coderch.

En este momento se inicia un ciclo de investigación conjunta entre el estudio Coderch-Valls y la empresa; ciclo que llevará a registrar patentes y modelos de utilidad de los característicos diseños de persianas de lamas abatibles. Llambí se encargaría también, además de la carpintería de obra, de la producción de mobiliario, como la tumbona Barceloneta de Correa-Milá o la lámpara Disa de Coderch (1957). Como se ha evocado reflexivamente, la asociación entre Coderch y Llambí -y otro tanto podría decirse de la de Fisac y La Navarra- es un caso notable de encuentro entre la tradición menestral y el nuevo diseño. Los artesanos partían de soluciones ortodoxas como resultado de procedimientos pautados y aprendidos por imitación. Los diseñadores ensayaban soluciones nuevas que requerían procedimientos diferentes. El trabajo de colaboración 
concienzuda y continuada fue una experiencia de entrecruzamiento entre la tradición constructiva que provenía del pasado artesanal con la anticipación proyectual que se volcaba en el progreso de la arquitectura y el diseño. ${ }^{34}$

Ahora bien, no estamos ante una artesanía de carácter rural idealizada desde la ciudad. Se trata de talleres urbanos con voluntad de crecimiento y ambición empresarial. Gracias a la colaboración con arquitectos y a una actualización tecnológica y de conocimientos, éstos se fueron reorganizando hasta devenir empresas de tamaño medio con una producción especializada. Con todo, la renovación del mercado del mueble requería introducir nuevas iniciativas en la red de suministros. Este es el papel que jugarían, a partir de la década de los sesenta, tiendas con un catálogo de edición propio completamente volcado al diseño. Para los casos que nos ocupan, hablamos de Darro en Madrid, constituida en 1959, y que incorporaría a su catálogo la butaca Toro en las dos versiones de estructura de madera y acero; y de Gres en Barcelona, que comercializaría la tumbona Barceloneta a partir de $1963 .{ }^{35}$

$* \quad * \quad *$

A medio camino entre el diseño privativo de una obra y un producto plenamente comercial, se encontraban Toro y Barceloneta en 1957. Su origen ya se ha comentado, pero también es cierto que se trataba de unos modelos que iban alcanzando un reconocimiento entre otros arquitectos y una comunidad selecta de consumidores y que tal potencialidad tendría su curso más comercial en la década que estaba en ciernes. Bien es cierto que la realidad productiva fue muy terca y aquello que rememoramos fueron más las excepciones que la norma. El gusto decorativo conservador siguió siendo dominante. ${ }^{36}$ Pero el diseño, a pesar de llegar solo a unas minorías, fue ganando mayor protagonismo e incidencia cultural en las décadas posteriores.

Puede concluirse que los diseños de Toro y Barceloneta interpretan los dos ejes en los que pivotaban los asuntos más candentes de aquel momento. No eran producto de la artesanía tradicional sino diseños nacidos de una consistente cultura proyectual y con una vocación de modernidad. Pero tampoco eran productos industriales, pues eran manufacturas de talleres de carpintería. Su fabricación estaba muy condicionada por el encargo de los propios arquitectos y su aceptación no excedía un público muy limitado. Sin embargo, daban idea de las posibilidades de actualizar las manufacturas de base artesana gracias a la intervención del arquitecto como diseñador.

En el marco de reflexiones más especulativas que tensionaban artesanía y diseño industrial, aquellos asientos presentaban un estado de la cuestión polémico. Por un lado, proveían de un mobiliario actualizado, adaptado a nuevas necesidades e ideas del confort y gusto. Cada uno a su manera, no renunciaban sino ostentaban posibles ancestros vernáculos, pero evitaban, con refinado diseño, confundirse con ellos. Otros modelos de aquellos años -no muchos- podían haber sugerido connotaciones más "industriales", aunque la selección de la Trienal estaba subordinada a la dramatización de una idea de España. Una idea de España que estaba muy arraigada en algunos cenáculos renovadores y regeneracionistas de aquellos momentos: la de ser un país que podía alcanzar 
la modernidad sin renunciar a la tradición. El desordenado desarrollo social y cultural de la década siguiente vino a demostrar que no, y lo hizo con una brusquedad destemplada.

\section{NOTAS}

${ }^{1}$ Andrés Canovas (ed), Fisac: Medalla de Oro de la Arquitectura (Madrid: Ministerio de Fomento, Consejo Superior de los Colegios de Arquitectos de España, 1997), 14.

${ }^{2}$ AFF: "Serie estructural", Archivo Fundación Fisac (consultado el 08-07-2020). Reproducido en Francisco Arqués Soler, Miguel Fisac (Madrid: Pronaos, 1996), 50-51.

${ }^{3}$ Hasta el momento, no tenemos constancia de que la denominación "butaca Toro" aparezca antes del catálogo de Darro de 1960, la empresa que lo editó a partir de aquella fecha. Ni siquiera en el listado "Relación de objetos enviados a la XI Trienal de Milán" de 1957 aparece con nombre alguno, solo "sillas de M. Fisac" ("Relación de objetos enviados a la XI Trienal de Milán". AMAE Leg. R. 11069 Expte 1). No cabe duda de que el nombre deriva de la propia apariencia de la butaca, pero desconocemos si tal atribución se debe al autor, a la divulgación espontanea, a la empresa Darro o a una combinación de todo lo anterior.

${ }^{4}$ Rodrigo Almonacid, "Una capilla, unas patas de gallinas y un par de horquillas (Coderch, Fisac y de la Sota)," en Pioneros de la arquitectura moderna española: vigencia de su pensamiento y obra, ed. Teresa Couceiro (Madrid: Fundación Alejandro de la Sota, 2015), 277.

${ }^{5}$ En realidad, el gusto por el mueble de estilo y los conjuntos de la vivienda burguesa (comedor, habitación, salón...) fueron el modelo dominante durante aquellos años del franquismo. Obviamente, a medida que el estrato social descendía y los recursos económicos eran más escasos, se producía un deterioro de la calidad del mueble y de la interpretación del estilo hasta llegar a extravíos y deformidades de pelaje muy deslucido. El patrón de conducta, sin embargo, era el aparentar a toda costa un estatus superior al que realmente se disponía.

6 "Casa en Cadaqués: J. A. Coderch de Sentmenat, M. Valls Vergés, arquitectes," Cuadernos de arquitectura no. 34 (1958): 23-26.

${ }^{7}$ Por otra parte, en 1962 Correa y Milá rediseñaron completamente el asiento para amueblar el club social del nuevo edificio del Colegio Oficial de Arquitectos de Cataluña y Baleares en Barcelona. Además de los brazos de cuero, agregaron un cojín en el asiento y macasar (o tapete) en el respaldo, pero el programa y el resultado resultan muy diferentes. Este es el modelo fue editado por Gres durante años.

${ }^{8}$ Anty Pansera, Storia e cronaca della Triennale (Milán: Longanesi, 1978): 428.

9 Juan Ramírez de Lucas, "El Pabellón español en la XI Trienal de Milán," La Hora. Arte, Letras y Política no. 51 (junio 1957): 16-17.

${ }^{10}$ Además del pabellón consiguieron premio de oro las cerámicas de Cumella y de plata las maletas de Loewe y las telas de Clara Szabé. No todo fueron alegrías y la obtención de algunos galardones fue diplomáticamente laboriosa. Una carta del embajador español en Roma revela que se tuvo que luchar para la concesión de la Medalla de oro al pabellón y no hubo opción, como en ocasiones anteriores, al Gran Premio, que recayó en el pabellón de Finlandia. La ausencia de Vázquez Molezún, que era el miembro español del jurado, no ayudó en absoluto. Carta del Embajador de España en Italia a la Dirección General de Relaciones Culturales, Roma, 25 de noviembre 1957. AMAE Leg. R. 11069 Expte 1.

${ }^{11}$ Juan Ramírez de Lucas, "Medalla de oro al pabellón de España en la XI Trienal de Milán," $A B C$ (24-12-1957): 45.

${ }^{12}$ Joaquín Vaquero Turcios, "Crisis en la Trienal," Revista Nacional de Arquitectura no. 191 (noviembre 1957): 33. 
${ }^{13}$ José M. García de Paredes, "Memoria de la estancia en la Academia Española de José M. García de Paredes. Memoria de la estancia en la Academia Española de Bellas Artes en Roma. Marzo 1958”. Citado en: Ángela García de Paredes, La arquitectura de José M. García de Paredes. Ideario de una obra (Tesis doctoral, Escuela Técnica Superior de Arquitectura UPM, 2015), 138.

${ }^{14}$ Gio Ponti, "La Spagna alla Triennale," Domus no. 300 (1954): 46. Citado en: "El Gran premio de la Trienal de Milán al pabellón español," Revista Nacional de Arquitectura no. 156 (1954): 26. ${ }^{15}$ Joaquín Vaquero Turcios, "Premios en Milán," Boletín de Información de la Dirección General de Arquitectura no. 21 (1951): 20.

${ }^{16}$ Oriol Bohigas, "El diseño industrial en la XI Trienal de Milán", Revista de actualidades, artes $y$ letras 298 (diciembre 1957 - enero 1958): 10.

${ }^{17}$ Bohigas, "El diseño industrial en la XI Trienal de Milán," 10.

${ }^{18}$ José M. García de Paredes, "Memoria de la estancia en la Academia Española de José M. García de Paredes. Memoria de la estancia en la Academia Española de Bellas Artes en Roma. Marzo 1958". Citado en: Ángela García de Paredes, La arquitectura de José M. García de Paredes. Ideario de una obra (Tesis doctoral, Escuela Técnica Superior de Arquitectura UPM, 2015), 139.

${ }^{19}$ La nota informativa de Carvajal es un documento interno de mayo de 1957 donde da cuenta al Ministerio de Asuntos Exteriores del proyecto mediante una descripción sumaria de la instalación y los objetos expuestos. Reproducimos el párrafo al que hacemos referencia:

Las paredes fuertemente iluminadas deslumbradoras de blanco, sobre un pavimento de "azulejos" crean el recinto mediterráneo luminoso y fresco, la reja interior que se encierra en él y encierra la aportación española, pone el contrapunto de dureza y frialdad industrial, expresión actual de la trágica fuerza de nuestra rejería de catedral y de cortijo, creando el mágico círculo de nuestro ruedo ibérico.

"Nota informativa" firmada por Javier Carvajal al Ministerio de Asuntos Exteriores. Exposiciones. Mayo 1957. AMAE Leg. R. 11069 Expte 1.

${ }^{20} \mathrm{El}$ contraste de la lista de envíos del Ministerio y la relación del catálogo de la Trienal permite observar estos ajustes que el análisis de las fotografías ratifica visualmente.

21 "Relación de objetos enviados a la XI Trienal de Milán," AMAE Leg. R. 11069 Expte 1.

22 "Nota informativa" firmada por Javier Carvajal al Ministerio de Asuntos Exteriores. Exposiciones. Mayo 1957. AMAE Leg. R. 11069 Expte 1.

${ }^{23}$ La Junta Gestora creada a tal efecto estuvo formada por Antoni de Moragas, presidente; Alexandre Ciricl Pellicer. vicepresidente; Pau Monguió, secretario; Hermenegildo Passola. tesorero: Oriol Bohígas, Ramon Marinel-lo, Wifredo Ricard, Alfons Serrahíma, Manuel de Solá Morales, Manual García Madurell y Juan Vallvé, vocales. La noticia apareció en los periódicos barceloneses ("Formación del Instituto de Diseño Industrial," La Vanguardia (6-07-1957): 21.) y el manifiesto íntegro en el semanario Revista ("Manifiesto del Instituto del Diseño Industrial," Revista de actualidades, artes y letras 258 (julio 1957): 12 y 19). La iniciativa no prosperaría por problemas con la organización sindical franquista, pero dio pie, pasado un tiempo, a la fundación del ADI, Agrupación de Diseño Industrial del FAD en 1960. Durante largo tiempo esta sería la única asociación española de diseño industrial y eje articulador de premios e iniciativas. ${ }^{24}$ Finalmente, y también por problemas de registro, la E de "Española" fue substituida por una E de "Estudios". El SEDI funcionó como una sociedad que promocionaba el diseño y respondía a encargos puntuales o realizaba propuestas para empresas vinculadas a la entidad, como Rolaco, Darro, H Mubles, Roca y Bidasoa. Entre su círculo de allegados también estaba Fisac, Fernando Ramón y Jose Picardo que trabajaban para alguna de estas firmas.

${ }^{25}$ C. M. (Carlos de Miguel), "Diseño industrial. Asociación española del diseño industrial," Revista Nacional de Arquitectura no. 185 (mayo 1957): 36.

${ }^{26}$ En las listas que constan en los archivos de la Trienal y del Ministerio de Asuntos Exteriores los dos ejemplares de la Barceloneta se identifican como " 2 sillas de Coderch, Correa y Milá". Así 
se atribuyen también en el artículo citado de Bohigas. Hoy la autoría se reconoce íntegramente a Correa y Milá. "Relación de objetos enviados a la XI Trienal de Milán," AMAE Leg. R. 11069 Expte 1.

${ }^{27}$ Miguel Fisac, "La casa de viviendas en Madrid," Revista Nacional de Arquitectura no. 118 (octubre 1951): 42.

${ }^{28}$ Raquel Pelta Resano, "La artesanía bajo el régimen de Franco," en Primer Simposio de la Fundació Història del Disseny, Modernos a pesar de todo (Barcelona: FHD, setiembre 2015) [Consultado 12 julio 2020] http://www.historiadeldisseny.org/wp-content/uploads/RaquelPelta-La-artesan--a-bajo-el-r--gimen-de-Franco.pdf.

${ }^{29}$ C. M. (Carlos de Miguel), "Diseño industrial. Asociación española del diseño industrial," 36.

${ }^{30}$ Antoni de Moragas, "Exposición GR: industria y arquitectura," Cuadernos de Arquitectura no. 18 (1954): 18 y 29.

${ }^{31}$ María Paz Aguiló, "Espacios interiores y mobiliario de Miguel Fisac para el CSIC," Informes de la Construcción vol 58, 503, (julio- septiembre 2006): 58.

${ }^{32}$ En el catálogo de Darro de 1960, con fotografías de J. Miguel Pando de 1959, aparecen los dos modelos, en madera y metal.

${ }^{33}$ El primer prototipo de la Superleggera es de 1949, perfeccionado en un segundo de 1951 y que adquiere su forma definitiva entre 1955 y 1957 cuando será producida por Cassina y presentada en la XI Trienal. La principal característica de la Superleggera es la reducción en peso y su esbeltez que le confieren una peculiar elegancia.

${ }^{34}$ Josep M. Martí, profesor de la Universidad de Barcelona, ha provisto de estas reflexiones en un artículo en el que rememora su propia experiencia de trabajo en el departamento técnico de la empresa Llambí. Josep M. Martí i Font, "A2 = D. Memòria personal del dissenya l'inici dels anys seixanta del segle XX," en La formació del Sistema Disseny Barcelona (1914-2014) Un camí de modernitat. Assaigs d'història local, coor. Anna Calvera (Barcelona: Publicacions i Edicions de la Universitat de Barcelona, 2014), 341.

${ }^{35}$ Barceloneta ha venido comercializándose con alguna interrupción. Entre 1954 y 1960 fue directamente Llambí-Dissa. Entre 1963 y 1978 estuvo a cargo de Gres. A partir de 1994 la reeditó, en su versión original, Santa \& Cole, Ediciones de Diseño.

${ }^{36}$ En cualquier caso, aun comercializadas, las ventas y aceptación de este tipo de piezas distaron mucho de ser equiparables a objetos similares de firmas italianas o escandinavas. 